\title{
The EMU Integration Structure and the Spillover Dynamics Towards the IAS Harmonization
}

\author{
G.A. Karathanassis \\ Athens University of Economics and Business \\ V.I. Sogiakas \\ Athens University of Economics and Business \\ S. Spiliotis \\ Athens University of Economics and Business
}

\begin{abstract}
This paper investigates the relationships among the European Monetary Union capital markets taking into account possible structural changes with respect to the harmonization procedure of the International Accounting Standards (IAS). According to many analysts, IAS could possibly contribute to the transparency of the transmitted information, the direct accessibility to the fundamentals of listed firms and the uniform manipulation of accounting data not only within exchanges but also between them. Based on the above, it is expected that the financial markets should react to the IAS harmonization with tighter relationships. This paper examines empirically the IAS implementation procedure in the EMU area and its impact on the relationship of the financial markets involved. By application of regime shift methodologies, the empirical findings of the paper are consistent with the hypothesis that the IAS harmonization process contributed to the informational efficiency and the transparency of financial markets, with higher degrees of interdependencies.
\end{abstract}

\footnotetext{
*Corresponding address: G.A. Karathanassis: Athens University of Economics and Business, Department of Business Administration (DBA), Patision 76, 10434, Athens, Greece, Tel: +30-210-8203272, E-mail: gkarath@aueb.gr / V.I. Sogiakas: Athens University of Economics and Business. DBA, E-mail: sogiav@aueb.gr / S. Spiliotis: Athens University of Economics and Business. DBA, E-mail: spilioti@aueb.gr C2011-Center for Economic Integration, Sejong Institution, Sejong University, All Rights Reserved.
} 
- JEL Classification: C22, C52, C53, G15

- Keywords: Cointegration, Spillover Effects, Regime Shift

\section{Introduction}

The EMU was established ïn $1^{\text {st }}$ January 1999 for eleven European Union members. The common currency was the euro and since then, the exchange rates were fixed for the EU-12, including Greece, which formally joined the EMU, two years later, on $1^{\text {st }}$ January 2001. In the EMU environment, the European Central Bank monetary policy is uniform among all countries and this contributes to the convergence of the money and the bond markets. However, a research question that arises is the investigation of the level of cointegration for the EMU financial markets.

On the other hand, in September 2002, the International Accounting Standards Board (IASB) and the Financial Accounting Standards Board (FASB) decided to contribute to the development of high quality, fully compatible financial reporting standards that could be applied either for domestic or foreign purposes. The result is the convergence between the US Generally Accepted Accounting Principles (US GAAP) and the International Financial Reporting Standards (IFRS), ${ }^{1}$ which imposes two pillars, the short term directions ${ }^{2}$ and the long term perspectives. ${ }^{3}$ Thus, after the resolution of the European Parliament on June 2002, regarding the compulsory adoption of the International Financial Reporting Standards (IFRS) by all EU listed companies by 2005, European Union countries were presented with the following alternatives: i. require or permit IFRSs for unlisted companies, ii. require or permit IFRSs in parent company (unconsolidated) financial statements, iii. permit companies whose only listed securities are debt securities, delay IFRS adoption until 2007, and iv. permit companies that are listed on exchanges outside of the EU and that currently prepare their primary financial statements using a non-EU GAAP (in most cases this would be US GAAP) to delay IFRS adoption until 2007.

The aim of the International Accounting Standards Board (IASB) and the

\footnotetext{
${ }^{1}$ IFRS, includes International Accounting Standards (IAS) issued by the predecessor body to the IASB. ${ }^{2}$ The short term directions, fill the gap between the IFRS and US GAAP at an individual level, such as accounting treatments of nonmonetary exchanges, discontinued operations, income taxes and interim reporting.

${ }^{3}$ Long term perspectives from the IASB - FASB point of view which could constitute a significant improvement in terms of accounting guidance, such as the joint projects on revenue recognition and purchase method procedures and the coordinated project on share-based payments.
} 
Financial Accounting Standards Board (FASB) convergence efforts was to make US Generally Accepted Accounting Principles (US GAAP) and International Financial Reporting Standards (IFRS) very close together between the financial markets involved, as well as improving the overall performance of their application. The convergence activities of the IASB and the FASB depend on the worldwide economic conditions and the regulative activity of the international financial system authorities, the origins of which have been proposed many years ago by the International Accounting Standards Committee (IASC). The motivation for the establishment of the (IASC) was the introduction of a common international language of accounting to serve capital markets. A common set of accounting standards improves the comparability of listed companies across countries. The importance of the IAS is enhanced especially for those countries which lack an established set of national accounting standards. The IASC had not the power to enforce adoption of its standards, and hence, it had to rely on persuading individual companies or national regulators.

The objective of this paper is the investigation of the relationship between the $\mathrm{EMU}^{4}$ financial markets within the framework of the IAS adoption. The guidance of the IAS structure, embeds a framework with transparency of accounting data, common practices of the reporting systems of listed companies within and between financial markets and disclosure of financial data that might affect the dynamics of the interdependencies of financial markets.

In this framework, the investigation of the possible effects of the implementation of IAS on the underlying financial environment, could be of crucial importance for regulators in order to develop further the disclosure of financial and accounting data towards the effective functioning of capital markets.

However, many companies have adopted optionally the implementation of IAS prior to 2005 when all firms compulsory adopted them. Thus, the econometric part of this topic is very demanding since it requires non-linear models in order to account for possible regime shifts in the dynamics of the relationship between the examined capital markets.

To this end, we applied regime shift econometric methods and found evidence that the common accepted accounting platform, which was adopted obligatory in

\footnotetext{
${ }^{4}$ The EMU and the common currency was established in order to contribute to the reduction of interest rates, the price transparency, the removal of transaction costs and the stability of exchange rates. In this direction, the purpose of the common currency was the financial integration, which causes higher economic growth rates, enhances the effective transmission of monetary policy impulses and finally, assures a stable financial environment.
} 
2005, has affected the way EMU financial markets inter-react with each other. More specifically, the long run equilibrium structure is better determined in the IAS sub-period, since the number of cointegration vectors is reduced from five to two in the post IAS period, with many implications for international finance, especially on the diversification benefits of international portfolios. Moreover, the dynamics of the spillover effects, show a higher rate of anticipated information, with lower persistence of volatility, in the second subperiod. Finally, according to the impulse response analysis the dependencies of the financial indexes are stronger, with higher magnitude and persistence, with an exception to the CAC 40, S\&P/MIB and PSI 20 financial indices.

The rest of the paper is organized as follows. Section II provides a brief discussion of the literature, while section III describes the data and the econometric methodology. Section IV presents the empirical findings, while Section V concludes our analysis.

\section{Literature Review}

There are many researchers who have investigated the relationship between the EU capital markets. More specifically, Haug, MacKinnon and Michelis (2000), concluded that not all of the twelve countries could form a successful EMU over time without the adoption of significant adjustments, which are focused on the potential painful long run policy structural changes. Siriopoulos (2000) stated that a common currency constitutes a regime shift, which pervades the very structure of markets and the fundamental attitudes of operators, forcing profound changes. Moreover, Hardouvelis, Malliaropoulos and Priestley (2006), concluded that there exist significant cointegration specifications between the EU financial markets which are Eurozone-specific phenomena, independent of a possible simultaneous world-market integration. However, Brealey (1999) and many distinguished panelists of a roundtable discussion, argued that an integrated structure of many different economies and financial markets is not an easy task and that it requires a tight regulative framework to be built. They focused on the Nash equilibrium in a frictionless environment, like EMU, the role of Pan-European index-led exchanges and other smaller ones, the corporate governance, the market efficiency, the independence of individual financial markets and the microstructure of financial markets.

On the other hand there are many researchers who have investigated the 
importance and the role of the IAS adoption. Among them, Gray (1980) in an empirical study, investigated differences of international accounting practices and their possible impact on the financial environment in the Eurozone, with respect to the profits. The consequences is that accounting principles tend to be applied in practice is such a way that the disclosure of company performance is based in the direction of relative conservatism or optimism as user needs indicate and managerial interests dictate. Hopwood (1994), investigated the IAS harmonization procedure with many implications on the understanding of supranational accounting policy-making and the significant role played by the audit industry and its agents. Sunder (2002), investigated the regulatory competition between the local monopoly in financial reporting standards and the structure of optional application of two or more sets of competing standards, with respect to the corporate financial environment. His empirical study, sheds much light on the debate regarding the merits of quality and the efficiency of available information in the financial market. Whittington (2005), investigated the structure of the IASB and its role as a global standard setter with many implications for the reporting financial performance. Schipper (2005), investigated the implementation effects of the mandated adoption of IAS in EU and underlined the necessity for detailed implementation guidance and for a single European securities regulator. Meulen, Gaeremynck and Willekens (2007) investigated the harmonization process in accounting standard setting from the market-based earnings point of view and concluded that the US GAAP accounting information outperforms IFRS, a result which is not fully valued by investors. Dewing and Russell (2008) in an empirical study examine the harmonization procedure of the IAS and concluded that there exist significant difficulties in forming a European view, since the IAS seem to reflect Anglo-Saxon accounting practices rather than European practices. Al-Shiab (2008) examined empirically through a VECM model, the consequences of the implementation of the IAS adoption on the cost of capital in Jordanian companies listed on the Amman Stock Exchange and found insignificant relationships. Armstrong, Barth, Jagolinzer and Riedl, examined empirically the reaction of European Stock Markets to sixteen events associated with the adoption of the IAS in Europe. According to their findings they concluded that there exists an incrementally positive reaction for firms with lower quality pre-adoption information, an incrementally negative reaction for firms domiciled in code law countries and a positive reaction for firms with high quality pre-adoption information. 


\section{Data and Research Methodology}

For the purposes of our analysis we drew data from the EU-12, as well as the UK and US financial markets. Although, the accounting regulation applies not only to full members of the European Union but also to members of the European Economic Areas, this paper focuses on the EU-12, in order to filter the analysis from spurious results, since the EMU impact is very likely to influence our empirical findings. The data correspond to weekly spot prices of the major financial indices of the countries under investigation, covering a period from $01 / 01 /$ 2000 to 14/08/2009, as shown in Table 1 below and on Figures $1 \& 2$ of the appendix.

The analysis of the relationship of the EMU capital markets, is twofold. First is the examination of the hypothesis that capital markets, through a common established accounting basis, do jointly contribute to their long run cointegrated structure with tighter relationships. Second, is the examination of possible short run adjustments around the equilibrium states, implying a more informative financial system.

The main difference of these analysis is that the first one examines the first moment of the returns' distributions, while the second one, examines the second moment of the returns' distributions. Thus, cointegration analysis covers the long run relationships, while the short run analysis accounts for the spillover effects and the informational efficiency of the time series examined.

Initially we examine the existence of a unit root $\&$ the stationarity of the time

Table 1. Financial markets and major financial indices

\begin{tabular}{ccc}
\hline 1 & Austria & ATX \\
\hline 2 & Belgium & BEL20 \\
3 & Finland & OMX Helsinki 25 \\
4 & France & CAC 40 \\
5 & Germany & DAX \\
6 & Greece & Athex 20 \\
7 & Ireland & ISEQ 20 \\
8 & Italy & S\&P/MIB \\
9 & Luxembourg & LuxX Index \\
10 & Netherlands & AEX index \\
11 & Portugal & PSI-20 \\
12 & Spain & IBEX 35 \\
13 & UK & FTSE 100 \\
14 & US & S\&P 500 \\
\hline
\end{tabular}


Figure 1. EU-12, US \& UK financial markets in levels

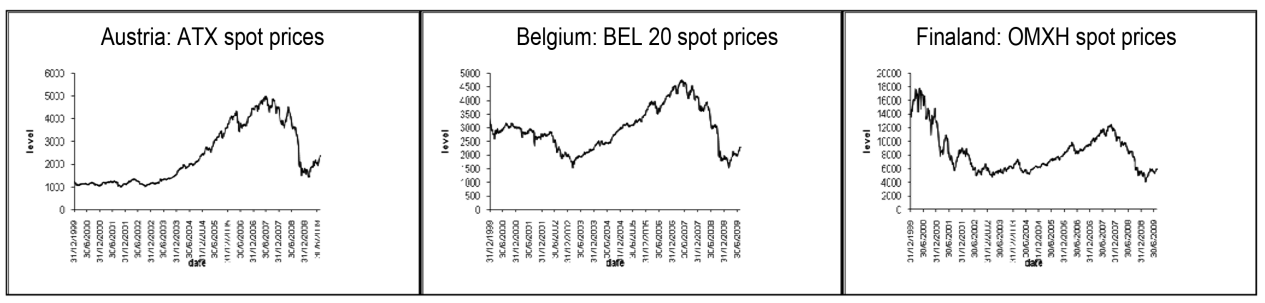

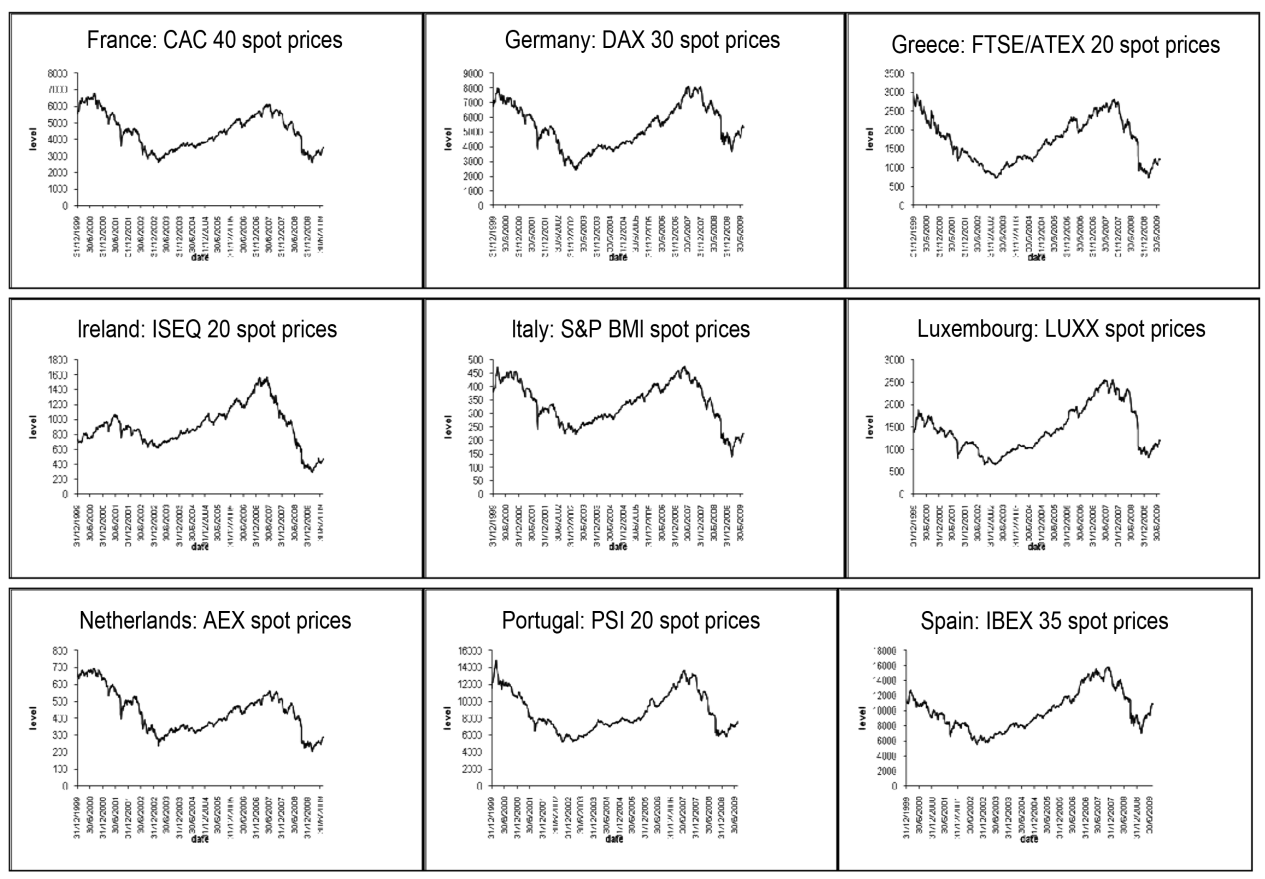

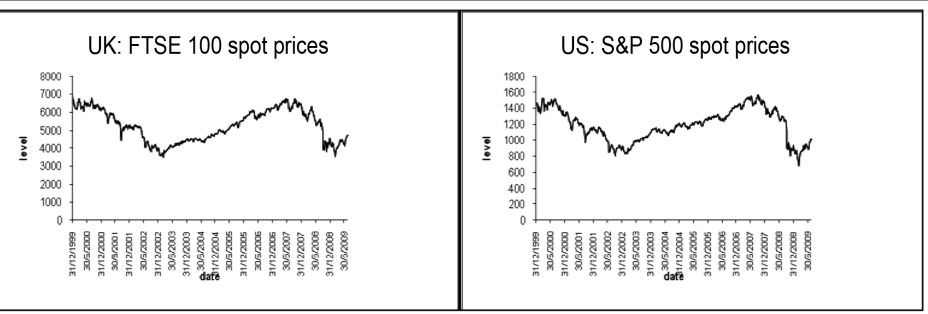


series using the DF (Dickey \& Fuller (1979)) and the KPSS (Kwiatkowski, Phillips, Schmidt \& Shin (1992)) tests, respectively, using weekly frequency of the data. $^{5}$

The examination of the stationarity conditions, is followed by the investigation of the long run relationship under the Johansen's $(1988,1991)$ cointegration framework. The statistical notion of cointegration of a set of non-stationary time series is derived by a linear combination of the time series vectors which is stationary. Thus, a set of cointegrated financial markets implies the existence of a common trend. The existence of $r$ cointegrating relations in a set of $n$ variables means that there must also exist n-r common stochastic trends that are nonstationary and move the system in short run adjustments around their equilibrium state(s). The cointegration mehtodology was extended by Johansen and Juselius (1990), Johansen and Juselius $(1992,1994)$ and Gonzalo and Granger (1995) who considered the restrictions that should be imposed in the VAR cointegration analysis, as shown below:

$$
\begin{gathered}
x_{t}=\mu+\prod_{1} x_{t-1}+\Pi_{2} x_{t-2}+\ldots+\prod_{k} x_{t-k}+\varepsilon_{t} \\
\text { or } \Delta x_{t}=\Pi \cdot x_{t-1}+\sum_{i=1}^{N} \sum_{j=1}^{k-1} \Gamma_{i j} \cdot \Delta x_{i, t-j}+\varepsilon_{t}
\end{gathered}
$$

where the residuals of equation (2) are assumed as independent identically random variables drawn from the zero mean Gaussian distribution with variance $\sigma^{2}$. The $\Pi, \Gamma$ matrices consist of the cointegration coefficients of the system. More precisely, the $\Pi$ matrix is partitioned into the ' $\beta$ ' coefficients that represent the long run equilibrium state of the system and into the ' $\alpha$ ' coefficients that represent the

\footnotetext{
${ }^{5} \mathrm{ADF}$ test:

$\Delta x_{t}=\alpha+\beta \cdot t+(\rho-1) \cdot x_{t-1}+\sum_{i=1}^{q} \psi_{i} \cdot \Delta x_{t-i}+\varepsilon_{t}$

(The estimation of the values of $p, q$ is based on AIC and/or BIC criterion)

$\mathrm{H}_{0}$ : the $\mathrm{x}_{\mathrm{t}}$ time series has a unit root on the characteristic polynom or $|\rho|=1$ KPPS test:$$
\mathrm{H}_{1} \text { : the } \mathrm{x}_{\mathrm{t}} \text { time series is stationary or }|\rho|<1 \text {, Statistic-t }=(1-\rho) / \text { s.e }(\rho)
$$

$x_{t}=f(r, t)+\varepsilon_{t}$ (The function $f(.,$.$) is a linear filter of the mean and trend of the time series)$

$\mathrm{H}_{0}$ : the $\mathrm{xt}$ time series is stationary vs. $\mathrm{H}_{1}$ : the xt time series is not stationary

$L M=\frac{\sum_{t=1}^{T}\left(\sum_{r=1}^{t} \varepsilon_{t r}^{2}\right)}{T^{2} \cdot f_{0}}$, where $f_{0}$ is the frequency domain estimation of the residuals at 0.
} 
short run adjustmnents around the common trend(s). ${ }^{6}$ Thus, the $x_{t}$ time series are cointegrated of order $r$, with cointegration vector ' $\beta$ '. In order to estimate the cointegration vector ' $\beta$ ' the Maximum Likelihood Estimation is applied. ${ }^{7}$ Hence, the likelihood ratio statistic of $\mathrm{H}_{0}$ (existence of at most $r$ cointegration vectors) is the following:

$$
-2 \cdot \ln (Q)=-T \cdot \sum_{i=r+1}^{p} \ln \left(1-\hat{\lambda}_{i}\right)
$$

where $\hat{\lambda}_{r+1}, \ldots, \hat{\lambda}_{p}$ are the ' $p-r$ ' lowest squared normal equinvalues. The rank of the cointegration vector is based on the following two statistics:

$$
\lambda_{\text {trace }}=-T \cdot \sum_{i=r+1}^{p} \ln \left(1-\hat{\lambda}_{i}\right), \lambda_{\max }=-T \cdot \ln \left(1-\hat{\lambda}_{r+1}\right)
$$

Thus, based on equations 3 and 4 the likelihood ratio statistic results is the following formulation:

$$
L=-T \cdot \sum_{i=r+1}^{p} \ln \left[\left(1-\hat{\lambda}_{i+(m-p)}^{*}\right) /\left(1-\hat{\lambda}_{i}\right)\right]_{\sim \mathrm{X}_{(\mathrm{n}-\mathrm{r})(\mathrm{n}-\mathrm{k})}}
$$

The cointegration analysis is fulfilled by the VECM model (Davidson, Hendry, Srba and Yeo (1978); Vector Error Correction Model):

$$
\Delta x_{t}=\sum_{v=1}^{N-r} \alpha_{v} \cdot V E C M_{v, t-1}+\sum_{i=1}^{N} \sum_{j=1}^{k-1} \Gamma_{i j} \cdot \Delta x_{i, t-j}+\varepsilon_{t}
$$

According to the VECM model it is possible to decompose the contribution of a

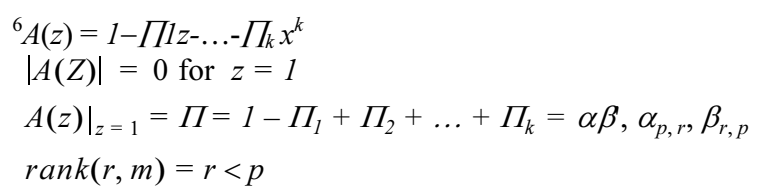

${ }^{7} i$. estimate the $\mathrm{r}$ higher squared correlations of the residuals $\left(\varepsilon_{t}\right)$ of $x_{t-1}$ and $\Delta x_{t-1}$ on $\Delta x_{t-1}, \ldots, \Delta x_{t-k}$

$$
S_{i j}=\frac{1}{T} \cdot \sum_{t=1}^{T} \varepsilon_{i t} \cdot \varepsilon_{j t}^{\prime} \text { and calculate the Sij term: }
$$

ii. define the pair of the tested hypothesis

$\mathrm{H}_{0}: \operatorname{rank}(\Pi) \leq r$ or $\Pi=\alpha B^{\prime}$

$\mathrm{H}_{1}: \operatorname{rank}(\Pi)=\mathrm{r}+1$

iii. under the validity of the $\mathrm{H}_{0}$ the MLE estimators of $\alpha, \beta$, coefficients are derived by the minimization of the following term with respect to the equinvalue ' $\beta$ ': $\left|S_{00}-S_{0 k} \cdot \beta \cdot\left(\beta^{\prime} \cdot S_{k k} \cdot \beta\right)^{-1} \cdot \beta^{\prime} \cdot S_{k 0}\right|$ where $\beta$ is a vector with the highest $r$ equinvalues that derive by the maximization of the term $S_{k 0} \cdot \beta \cdot S_{0 k}$ with respect to the $S_{k k}$ standardized term $\left(\beta^{\prime} \cdot S_{0 k} \cdot \beta=I\right)$ and $\hat{a}=S_{0 k} \cdot \beta$ 
single financial market or a group of them in the formulation of the equilibrium state.

However, many companies have adopted optionally the implementation of IAS prior to 2005 when all firms compulsory adopted them. Thus, the econometric part of this topic is very demanding since it requires non-linear models in order to account for possible regime shifts in the dynamics of the relationship between the examined capital markets. To the best of the authors' knowledge there is no relevant paper.

The investigation of the relationship of a set of financial markets depends on many macroeconomic and microeconomic factors of the countries examined that is not feasible to account for. For that reason simple or conventional econometric methodologies could not explain the structure and the relationships between the financial markets unless non-linear factors and markov switching methodologies are incorporated into econometric analysis. Regime shift models produce better results in terms of both statistical fit and predictive power, compared with conventional models. Furthermore, non-linear models allow for explosive shifts found in the mean of the variance process of the underlying returns. Even though the effect of a rare event, like a market crash, a new regulative policy, a new government policy, a new market, or a new financial disclosure policy, might be temporary, the magnitude of a rare event can have very serious effects on the estimation of time series models. Finally, there is a fundamental difference between the structural break and the regime shift methodology. Thus, when utilizing dummy variables in order to investigate structural break points (IAS implementation), the analysis is constrained to account only for possible structural shifts that have taken place on the introduction date of futures contracts. However, this is not the case at all times, since these hypothetical spill over effects may lead up or delay for a short period of time. Again, MSVECM and SWARCH methodologies overcome such difficulties and limitations, offering robust results.

In order to account for stochastic regimes in the adjustment process around equilibrium states we apply the MS-VECM model (Krozlig1996,1997):

$$
\Delta x_{t}=\sum_{v=1}^{N-r} \alpha_{v}\left(s_{t}\right) \cdot V E C M_{v, t-1}+\sum_{i=1}^{N} \sum_{j=1}^{k-1} \Gamma_{i j}\left(s_{t}\right) \cdot \Delta x_{i, t-j}+\varepsilon_{t}
$$

where, $\mathrm{S}_{\mathrm{t}}$ is a latent variable which corresponds to the 'regime' of the VECM model and follows an endogenous markov chain with two levels.

In order to investigate the impact of the IAS adoption, on the volatility of the 
financial markets the SWARCH model of Hamilton \& Susmel (1994) is applied. According to the SWARCH model there exists a latent variable $\left(S_{t}\right)$ of three levels which represent the states of the whole process, according to the following equations:

$$
\begin{gathered}
\varepsilon_{t}=\sqrt{g_{s_{t}}} \cdot w_{t} \\
w_{t} \sim A R C H-L(2) \\
w_{t}=z_{t} \cdot \sqrt{h_{t}}, \quad z_{t} \sim \text { Student }-t(d \cdot f) \\
h_{t}=a_{0}+a_{1} \cdot w_{t-1}^{2}+a_{2} \cdot w_{t-2}^{2}+\xi \cdot w_{t-1}^{2}
\end{gathered}
$$

where $\varepsilon_{\mathrm{t}}$ are the residuals of the VECM model, $g_{S t}$ is the parameter which governs stochastically ${ }^{8}$ the $\mathrm{ARCH}$ process ( $g_{l}$ is normalized to unity), $w_{t}$ is a gaussian random variable (innovations) with time varying conditional volatility, $h t$ is the conditional volatility, $z_{t}$ is a homeskedastic random variable drawn from the student-t distribution, the SWARCH $\alpha_{i}$ coefficient represents the rate of information flow and the SWARCH $\xi$ coefficient represents the leverage effect in the volatility specification. ${ }^{9}$ The latent a variable $S_{t}$ corresponds to the 'State' or 'Regime' that the ARCH process is at time $t$ and is modeled through a markov chain of three levels, as follows:

$$
\begin{gathered}
P\left(S_{t}=j \mid S_{t-1}=i, \ldots, y_{t-1}, y_{t-2}, \ldots\right)=P\left(S_{t}=j \mid S_{t-1}=i\right) \\
P=\left[\begin{array}{lll}
p_{11} & p_{21} & p_{31} \\
p_{12} & p_{22} & p_{32} \\
p_{13} & p_{23} & p_{33}
\end{array}\right], \sum_{j}^{3} p_{i j}=1
\end{gathered}
$$

where $P\left\{p_{i j}\right\}$ is the transition matrix of the above states.

The spillover effects which might have taken place during the IAS adoption procedure could be investigated either in a multivariate framework, among EU-12,

${ }^{8}$ Conventional econometric approaches might be insufficient to explain the relationship between European Financial Markets due to the forward-looking nature of investors who set prices based on their expectations. ${ }^{9}$ In a risk aversion investment environment, current good news (positive returns) have a dampening effect on future spot volatility, the magnitude of which is lower than the increment effect on future spot volatility cause by current bad news (negative returns). 
Figure 2. EU-12, US \& UK financial markets in returns
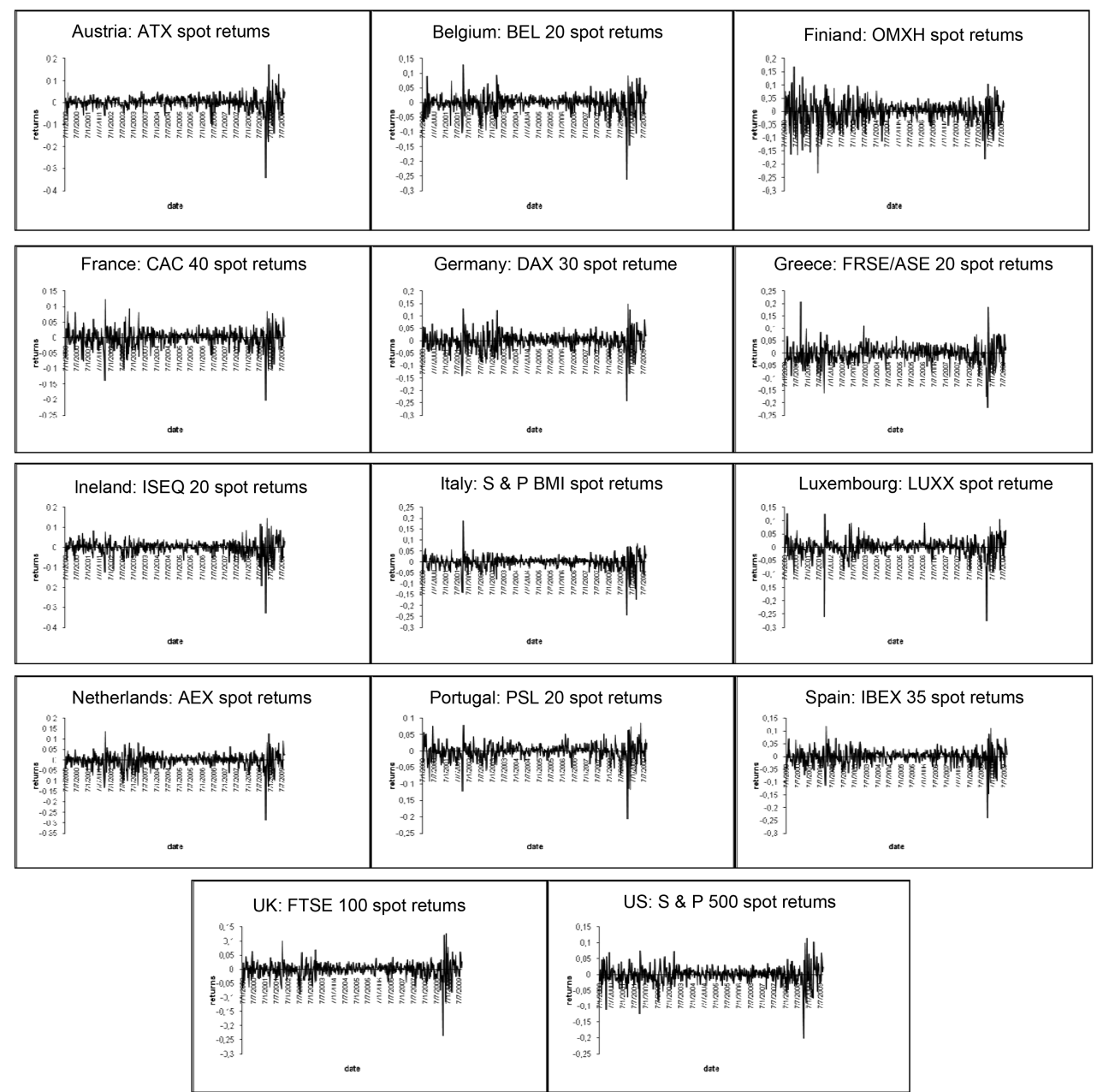

or a bivariate level examining the UK and US effect. For that reason we apply the Ledoit, Pedro and Wolf (2002) Flexible Diagonal VECH model:

$$
\begin{gathered}
x_{t}=f\left(z_{t}\right)+\varepsilon_{t} \\
\varepsilon_{t} \mid \Psi_{t-1} \sim F\left[0, H_{t}\right] \\
H_{t}=\Sigma+A \cdot\left(\varepsilon_{t-1} \varepsilon_{t-1}^{\prime}\right)+B \cdot H_{t-1}
\end{gathered}
$$

where the ' $f$ ' function demeans the data, the $\Sigma$ matrix denotes the unconditional 
Table 2a. Descriptive statistics for the EU-12, US \& UK financial markets in returns

\begin{tabular}{lcccccccccccccc}
\hline & ATX & BEL20 & OMXH & CAC40 & DAX30 & FTSE20 & ISEQ20 & SPBMI & LUXX & AEX & PSI20 & IBEX35 & FTSE100 & SP500 \\
\hline Mean & 0.001375 & -0.000766 & -0.001785 & -0.001012 & -0.000539 & -0.001724 & -0.000873 & -0.001154 & -0.000310 & -0.001686 & -0.000894 & -0.000131 & -0.000768 & -0.000758 \\
Median & 0.004644 & 0.002379 & 0.002902 & 0.001857 & 0.003030 & -0.000137 & 0.003763 & 0.002208 & 0.001704 & 0.000948 & 0.000534 & 0.003104 & 0.001402 & 0.000958 \\
Maximum & 0.172263 & 0.129057 & 0.168428 & 0.123448 & 0.149421 & 0.207474 & 0.144709 & 0.186417 & 0.126315 & 0.135816 & 0.085059 & 0.118234 & 0.125845 & 0.113559 \\
Minimum & -0.341341 & -0.261109 & -0.231629 & -0.202068 & -0.243470 & -0.218591 & -0.328958 & -0.243455 & -0.273516 & -0.287546 & -0.205700 & -0.238266 & -0.236317 & -0.200837 \\
Std. Dev. & 0.034744 & 0.031333 & 0.045442 & 0.030532 & 0.036309 & 0.038596 & 0.037514 & 0.031993 & 0.034452 & 0.035354 & 0.025980 & 0.031478 & 0.027328 & 0.028078 \\
Skewness & -2.298168 & -1.462173 & -0.641156 & -0.831120 & -0.618116 & -0.251649 & -1.746534 & -1.305200 & -1.811048 & -1.249718 & -1.434566 & -1.102396 & -1.185988 & -0.858234 \\
Kurtosis & 24.78419 & 14.01975 & 5.533140 & 8.207364 & 8.171460 & 8.389638 & 16.41695 & 14.26408 & 17.32962 & 12.41098 & 12.72945 & 10.62998 & 15.85723 & 10.06843 \\
& & & & & & & & & & & & & & \\
Jarque-Bera & 10367.91 & 2718.891 & 168.6118 & 624.9833 & 591.3616 & 612.8898 & 4020.520 & 2796.424 & 4569.402 & 1983.187 & 2152.203 & 1319.376 & 3575.381 & 1106.678 \\
Probability & 0.000000 & 0.000000 & 0.000000 & 0.000000 & 0.000000 & 0.000000 & 0.000000 & 0.000000 & 0.000000 & 0.000000 & 0.000000 & 0.000000 & 0.000000 & 0.000000 \\
\hline
\end{tabular}

Table 2b. Descriptive statistics for the EU-12, US \& UK financial markets in returns for the pre IAS period

\begin{tabular}{|c|c|c|c|c|c|c|c|c|c|c|c|c|c|c|}
\hline & ATX & BEL20 & OMXH & CAC40 & DAX30 & FTSE20 & ISEQ20 & SPBMI & LUXX & AEX & PSI20 & IBEX35 & FTSE100 & SP500 \\
\hline Mean & 0.002712 & -0.000499 & -0.003259 & -0.001666 & -0.001883 & -0.002420 & 0.001198 & -0.000763 & -0.000299 & -0.002517 & -0.001737 & -0.000952 & $2-0.001590$ & -0.000738 \\
\hline Median & 0.004272 & 0.002358 & 0.001572 & 0.000403 & 0.000832 & -0.002138 & 0.003503 & 0.001707 & 0.000365 & 0.000146 & -0.001140 & 0.001604 & + 0.001339 & 0.000780 \\
\hline XMaximum & 0.050319 & 0.129057 & 0.168428 & 0.123448 & 0.128874 & 0.207474 & 0.080632 & 0.186417 & 0.126315 & 0.135816 & 0.078558 & 0.118234 & 0.100695 & 0.074923 \\
\hline Std. Dev. & 0.019909 & 0.028792 & 0.053772 & 0.031258 & 0.036874 & 0.036162 & 0.027594 & 0.028893 & 0.033766 & 0.034615 & 0.023440 & 0.029569 & 0.023836 & 0.026231 \\
\hline Skewness & -0.690992 & -0.197775 & -0.463824 & -0.175079 & -0.044765 & 0.481329 & -0.711427 & 0.021793 & -1.456347 & -0.332737 & -0.449220 & 0.028545 & -0.130082 & -0.569627 \\
\hline Kurtosis & 4.408739 & 6.035073 & 4.422858 & 5.330613 & 4.004345 & 8.103397 & 5.615132 & 12.34919 & 16.85879 & 4.772437 & 6.288741 & 4.073035 & 4.922064 & 5.898764 \\
\hline Probability & 0.000000 & 0.000000 & 0.000000 & 0.000000 & 0.003972 & 0.000000 & 0.000000 & 0.000000 & 0.000000 & 0.000000 & 0.000000 & 0.001876 & 0.000000 & 0.000000 \\
\hline
\end{tabular}


Table 2c. Descriptive statistics for the EU-12, US \& UK financial markets in returns for the post IAS period

Mean $-7.31 \mathrm{E}-05-0.001055-0.000190-0.0003040 .000917-0.000970-0.003116-0.001578-0.000322-0.000786 \quad 1.97 \mathrm{E}-05 \quad 0.000758-8.74 \mathrm{E}-05-0.000781$

$\begin{array}{lllllllllllllll}\text { Median } & 0.004996 & 0.002399 & 0.004578 & 0.002645 & 0.004759 & 0.002590 & 0.004450 & 0.004109 & 0.002937 & 0.001409 & 0.001786 & 0.004889 & 0.001536 & 0.001280\end{array}$

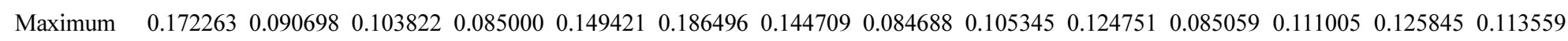

Minimum $\quad-0.341341-0.261109-0.179758-0.202068-0.243470-0.218591-0.328958-0.243455-0.273516-0.287546-0.205700-0.238266-0.236317-0.200837$

$\begin{array}{lllllllllllllll}\text { Std. Dev. } & 0.045678 & 0.033929 & 0.034254 & 0.029775 & 0.035707 & 0.041133 & 0.045860 & 0.035099 & 0.035250 & 0.036188 & 0.028498 & 0.033463 & 0.030701 & 0.030006\end{array}$

Skewness $\quad-1.974288-2.268372-0.978984-1.645939-1.296593-0.801365-1.736058-2.067082-2.146328-2.125952-2.031669-1.956527-1.708480-1.056732$

$\begin{array}{lllllllllllllll}\text { Kurtosis } & 16.93229 & 17.86607 & 6.551316 & 12.09857 & 13.52658 & 8.439549 & 14.25086 & 14.35183 & 17.69726 & 19.49807 & 15.49333 & 14.92597 & 19.02978 & 12.41525\end{array}$

$\begin{array}{llllllllllllll}\text { Jarque-Bera } 2105.737 & 2425.888 & 165.1400 & 940.1056 & 1180.233 & 322.9143 & 1392.152 & 1465.635 & 2354.133 & 2914.746 & 1733.131 & 1581.971 & 2697.487 & 935.0161\end{array}$

$\begin{array}{llllllllllllllll}\text { Probability } & 0.000000 & 0.000000 & 0.000000 & 0.000000 & 0.000000 & 0.000000 & 0.000000 & 0.000000 & 0.000000 & 0.000000 & 0.000000 & 0.000000 & 0.000000 & 0.000000\end{array}$

Table 3a. Correlations of the EU-12, US \& UK financial markets in returns

\begin{tabular}{|c|c|c|c|c|c|c|c|c|c|c|c|c|c|c|}
\hline & AEX & ATX & BEL20 & CAC40 & DAX30 & FTSE100 & FTSE20 & IBEX35 & ISEQ20 & LUXX & ОМХH & PSI20 & SP500 & SPBMI \\
\hline EX & & & 357076 & & & & 70976 & & & & & & 0.762105 & \\
\hline$\Gamma \mathrm{X}$ & & 00000 & 43473 & & & & 828 & & & & & & 566173 & \\
\hline EL20 & 57076 & 643473 & 00000 & 236 & 3062 & & & & & & & 217 & 2522 & 194 \\
\hline $\mathrm{AC} 40$ & 842694 & 0.603645 & 739236 & 000 & 727 & 0. & 501993 & 0.780165 & 540 & 0.739 & 0.642397 & 0.645 & 0.729558 & \\
\hline DAX30 & 0.88 & 0.590 & 63062 & & & & & & & & & & 291 & \\
\hline FTSE100 & 0.873313 & 0.670355 & 0.805822 & 318 & 491 & & 910 & & 266 & & & & 573 & 411 \\
\hline FTSE20 & 0.570 & 0.551828 & 0.538566 & 993 & 240 & & & & $0.4 \mathrm{C}$ & & & 0.535 & 2114 & \\
\hline IBEX35 & 0.815389 & 0.622977 & 0.734295 & 0.780165 & 0.847022 & 0.8 & 998 & 000 & 795 & & 793 & 0.7 & 3199 & 664 \\
\hline ISEQ20 & 0.681213 & 0.621061 & 0.678168 & 0.634540 & 0.636773 & 0.663266 & 0.497411 & 0.603795 & 1.000000 & 0.602787 & 6370 & 0.508 & 0.593989 & 0315 \\
\hline LUXX & 0.698 & 0.608 & & & & & & & & & & & 0.6 & 330 \\
\hline OMXH & 0.656628 & 0.408898 & 0.480465 & 0.642397 & 0.661363 & 0.644223 & 0.432228 & 0.627793 & 0.416370 & 0.450071 & 1.000000 & 0.569061 & 0.644025 & 0.603223 \\
\hline PSI20 & 0.652051 & 0.580385 & 0.597217 & 0.645269 & 0.687745 & 0.655058 & 0.535260 & & 0.508851 & & 0.569061 & & 0.571550 & 0.693333 \\
\hline SP500 & 0.762105 & 0.566173 & 0.682522 & 0.729558 & 0.800291 & 0.811573 & 0.492114 & & 0.593989 & 0.615 & 0.644025 & 0.571 & 1.000000 & 0.74863 \\
\hline SPBMI & 0.854463 & 0.634869 & 0.769194 & 0.829693 & 0.847310 & 0.842411 & 0.558665 & 0.843664 & 0.640315 & 0.705330 & 0.603223 & 0.693333 & 0.748636 & 1.000000 \\
\hline
\end{tabular}


Table 3b. Correlations of the EU-12, US \& UK (returns) for the pre IAS period

\begin{tabular}{|c|c|c|c|c|c|c|c|c|c|c|c|c|c|c|}
\hline & AEX & ATX & BEL20 & CAC40 & DAX30 & FTSE100 & FTSE20 & IBEX35 & ISEQ20 & LUXX & OMXH & PSI20 & SP500 & SPBMI \\
\hline AEX & 1.000000 & 0.299580 & 0.806947 & 0.830113 & 0.868110 & 0.820200 & 0.433580 & 0.781749 & 0.594938 & 0.518117 & 0.578745 & 0.532775 & 0.690360 & 0.825327 \\
\hline ATX & 299580 & .000000 & .325500 & 0.309901 & 0.294967 & 0.299222 & 0.265235 & 0.316604 & 0.324590 & 0.247975 & 0.071405 & 0.184073 & 0.202394 & 0.252958 \\
\hline BEL20 & 0.806947 & 0.325500 & 1.000000 & 0.667893 & 0.683559 & 0.697634 & 0.324225 & 0.615714 & 0.556864 & 0.439735 & 0.308965 & 0.365293 & 0.540455 & 0.652008 \\
\hline CAC40 & 0.830113 & 0.309901 & 0.667893 & 1.000000 & 0.818939 & 0.768144 & 0.485549 & 0.761477 & 0.607849 & 0.662151 & 0.578106 & 0.532657 & 0.687834 & \\
\hline DAX30 & 0.868110 & 0.294967 & 0.683559 & 0.818939 & 1.000000 & 0.791170 & 0.439494 & 0.796496 & 0.579532 & 0.525028 & 0.593264 & & 0.735309 & \\
\hline FTSE100 & 0.820200 & 0.299222 & 0.697634 & 0.768144 & 0.791170 & 1.000000 & 0.345499 & 0.719426 & 0.529362 & 0.450656 & 0.562466 & 0.492737 & 0.741046 & 0.781090 \\
\hline TSE20 & 0.433580 & 0.265235 & 0.324225 & 0.485549 & 0.439494 & 0.345499 & 1.000000 & 0.411716 & 0.306591 & 0.371671 & 0.312863 & 0.396 & 0.331246 & 0.406 \\
\hline IBEX35 & 0.781749 & 0.316604 & 0.615714 & 0.761477 & 796496 & 0.719426 & 0.411716 & 1.000000 & & 0.494186 & & & 0.634878 & \\
\hline ISEQ20 & 0.594938 & 0.324590 & 0.556864 & 0.607849 & 0.579532 & 0.529362 & 0.306591 & 489436 & 000 & 0.467247 & 0.264825 & 0.295213 & 0.508923 & \\
\hline LUXX & 0.518117 & 0.247975 & 0.439735 & 0.662151 & 0.525028 & 0.450656 & 0.371671 & 0.494186 & 247 & 1.000000 & 0.280627 & 0.346630 & 0.458698 & 0.6 \\
\hline OMXH & 0.578 & 0.071405 & 0.308965 & 0.578106 & 0.593264 & 0.562466 & 12863 & 013 & 825 & 0.28 & 1.000000 & & 0.5 & \\
\hline PSI20 & 0.532775 & 0.184073 & 0.365293 & 0.532657 & 0.598479 & 0.492737 & 0.396927 & 0.659106 & 0.295213 & 0.346630 & 0.515498 & 1.000000 & 0.420895 & 0.582730 \\
\hline SP500 & 0.690 & 0.202394 & 0.540455 & 0.687834 & 735309 & 0.741046 & 246 & 878 & & 0.45 & 0.5 & 0.4 & 0000 & \\
\hline SPBMI & 0.825327 & 0.252958 & 0.652008 & 0.818931 & 0.830593 & 0.781090 & 0.406185 & 0.799837 & 0.537270 & 0.604151 & 0.507377 & 730 & 0.66 & \\
\hline & AEX & & & & & & & & & & & & & \\
\hline$\overline{\mathrm{AEX}}$ & 1.000000 & 0.850127 & 0.904987 & 0.858106 & 0.895832 & 0.924390 & 0.696754 & 0.847186 & 0.767828 & 0.878619 & 0.832830 & 0.756647 & 0.829036 & 0.884936 \\
\hline ATX & 0.850 & 1.00 & 0.812593 & 691 & 0.811511 & 118 & 188 & 0040 & 1450 & 0.832717 & 0.8 & & 0.75 & \\
\hline BEL20 & 0.904987 & 0.812593 & 1.000000 & 0.817128 & 0.847550 & 5186 & 0.712464 & 0.831874 & 0.760596 & 0.856719 & 0.783642 & 0.773880 & 0.79 & 993 \\
\hline CAC40 & 0.858106 & 0.830691 & 0.817128 & 1.000000 & 0.859792 & 0.845636 & 0.722833 & 0.804504 & 0.697385 & 0.826714 & 0.790001 & 0.759466 & 0.777536 & \\
\hline DAX30 & & 0.811511 & 0.847550 & 792 & & 149 & 4053 & 1877 & 9436 & 0.798232 & 0.816860 & 0.777654 & 0.870580 & \\
\hline FTSE100 & 0.924390 & 0.839118 & 0.885186 & 0.845636 & 0.916149 & 1.000000 & 0.679868 & 0.874131 & 0.742340 & 0.806509 & 0.843386 & 0.767384 & 0.866289 & 0.886500 \\
\hline FTSE20 & 0.696754 & 0.713188 & 0.712464 & 0.722833 & 0.714053 & 0.679868 & 1.000000 & 0.684419 & 0.623032 & 0.674045 & 0.653750 & 0.643732 & 0.626246 & \\
\hline IBEX35 & 0.847186 & 0.800040 & 0.831874 & 0.804504 & 0.901877 & 4131 & 0.684419 & 1.000000 & 0.690492 & 0.774368 & 34004 & 0.797684 & 0.816035 & 0.88 \\
\hline ISEQ20 & 0.767828 & 0.711450 & 0.760596 & 0.697385 & 0.719436 & 0.742340 & 0.623032 & 0.690492 & 1.000000 & 0.714230 & 0.676635 & 0.636884 & 0.659063 & 0.707208 \\
\hline LUXX & 0.878619 & 0.832717 & 0.856719 & 0.826714 & 0.798232 & 0.806509 & & 0.774368 & 0.714230 & 1.000000 & 0.761053 & & 0.758745 & \\
\hline OMXH & 0.832830 & 0.811245 & 0.783642 & 0.790001 & 0.816860 & 0.843386 & 0.653750 & 0.784004 & 0.676635 & 0.761053 & 1.000000 & 0.712711 & 0.777667 & 0.813485 \\
\hline PSI20 & 0.756647 & 0.770591 & 0.773880 & 0.759466 & 0.777654 & 0.767384 & 0.643732 & 0.797684 & 0.636884 & 0.734141 & 0.712711 & 1.000000 & 0.689999 & 0.775993 \\
\hline SP500 & 0.829036 & 0.757643 & 0.796868 & 0.777536 & 0.870580 & 0.866289 & 0.626246 & 0.816035 & 0.659063 & 0.758745 & 0.777667 & 0.689999 & 1.000000 & 0.818041 \\
\hline SPBMI & 0.884936 & 0.819784 & 0.857993 & 0.852734 & 0.875463 & 0.886500 & 0.679428 & 0.880433 & 0.707208 & 0.795594 & 0.813485 & 0.775993 & 0.818041 & 1.000000 \\
\hline
\end{tabular}

$\begin{array}{llllllllllllllllllll}\text { SPBMI } & 0.884936 & 0.819784 & 0.857993 & 0.852734 & 0.875463 & 0.886500 & 0.679428 & 0.880433 & 0.707208 & 0.795594 & 0.813485 & 0.775993 & 0.818041 & 1.000000\end{array}$ 


\begin{tabular}{|c|c|c|c|c|c|c|c|c|c|c|c|c|}
\hline & & & $\begin{array}{l}\text { it Roo } \\
01 / 00-\end{array}$ & tatio & rests ft & & $101 / 00$ & & & & & \\
\hline & $\frac{\text { whol }}{\text { A }}$ & $\frac{\text { sample 0 }}{F^{*}}$ & $\frac{01 / 00-}{K}$ & $8 / 09$ & pre It & sample & $\frac{101 / 00}{K}$ & $\frac{01 / 05}{0.01}$ & post I & S sample & $\frac{1 / 01 / 05}{K}$ & 108/09 \\
\hline & level & 1st d & level & $1 \mathrm{std}$ & level & 1st d & level & $1 \mathrm{st} \mathrm{d}$ & level & 1st d & level & 1st d \\
\hline ATX & $-0,469$ & $-21,611$ & 0,302 & 0,176 & 0,604 & $-15,929$ & 0,445 & 0,101 & $-1,481$ & & 0,431 & 0,080 \\
\hline BEL20 & $-1,030$ & & 0,292 & 0,223 & $-1,079$ & $-13,076$ & & & $-1,325$ & $-9,262$ & & 0,115 \\
\hline OMx & $-2,125$ & $-24,057$ & 0,412 & 0,110 & $-2,005$ & $-17,583$ & 0,440 & 0,042 & $-1,131$ & $-15,546$ & & 0,105 \\
\hline CAC40 & $\begin{array}{l}0,837 \\
-1688\end{array}$ & $\begin{array}{l}-23,055 \\
-22\end{array}$ & 0,384 & 0,155 & $-1,196$ & $-16,943$ & 0,419 & 0,103 & $-1,526$ & $-15,647$ & & 0,09 \\
\hline $\begin{array}{l}\text { DAX } \\
\text { ATHEX } 20\end{array}$ & $\begin{array}{r}-1,688 \\
0,595\end{array}$ & $-22,848$ & 0,441 & 0,134 & $-1,050$ & $-15,375$ & 0,414 & 0,085 & $\begin{array}{l}-1,346 \\
-1286\end{array}$ & $-16,854$ & & 0,082 \\
\hline ISEQ & $-0,555$ & $-23,845$ & 0,317 & $\begin{array}{l}0,170 \\
0,170\end{array}$ & $\begin{array}{l}-1,2060 \\
-1,316\end{array}$ & $-15,434$ & & & $\begin{array}{l}-1,354 \\
-1,34\end{array}$ & $\begin{array}{l}-14,510 \\
-17,451\end{array}$ & & $\begin{array}{l}0,094 \\
0,162\end{array}$ \\
\hline S\&P/MIB & $-1,125$ & $-21,520$ & 0,320 & 0,16 & $-0,903$ & $-14,115$ & & & $-1,481$ & & & \\
\hline LUXX & $-1,268$ & $-12,642$ & 0,310 & 0,164 & $-0,512$ & $-14,625$ & 0,438 & 0,096 & $-1,233$ & -8, & & \\
\hline & $-1,641$ & $-22,058$ & 0,408 & 0,136 & $-1,473$ & $-16,184$ & 0,350 & & $-1,383$ & & & 0,074 \\
\hline & $-1,458$ & $-20,051$ & 0,368 & 0,1 & & $-13,9$ & & & & & & 0,121 \\
\hline IE & $-1,766$ & $-14,505$ & 0,346 & 0,157 & $-1,038$ & $-15,636$ & & & $-1,494$ & $-9,729$ & & \\
\hline FTSE-1 & 0,521 & $-24,354$ & 0,372 & & $-1,505$ & $-17,001$ & & 0,06 & $-1,798$ & $-17,338$ & 0,4 & \\
\hline S\&P5C & 57 & $-24,376$ & 0,302 & 0,124 & 315 & $-18,379$ & 0,460 & 0,064 & $-1,362$ & $-16,257$ & 0,414 & 088 \\
\hline $\begin{array}{l}\text { crit.values: } \\
\text { crit.values: }\end{array}$ & $\begin{array}{l}-3,91 \\
0,216 \\
-10\end{array}$ & $\begin{array}{l}\%),-3,41 \varepsilon \\
\% \text { \%), } 0,146\end{array}$ & $\begin{array}{l}\%),-3,1 \\
\text { \%), } 0,1\end{array}$ & & $\begin{array}{r}-3,9 \\
0,2 \\
\end{array}$ & $\begin{array}{l}(1 \%),-3,42 \\
1 \%), \quad 0,146\end{array}$ & o), -3 & & 3 & 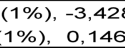 & $\begin{array}{l}\text { (lo), }-3 \\
\text { 6), } 0 \text {, }\end{array}$ & \\
\hline
\end{tabular}

Table 5. Cointegration Analysis

\begin{tabular}{|c|c|c|c|c|c|c|c|c|c|c|c|c|}
\hline \multicolumn{13}{|c|}{ Johansen's Cointegration Test for the EU-12, US \& UK financial markets } \\
\hline & \multicolumn{4}{|c|}{ whole sample 01/01/2000 - 14/08/2010 } & \multicolumn{4}{|c|}{ pre IAS period 01/01/2000 - 01/01/2005 } & \multicolumn{4}{|c|}{ post IAS period 01/01/2005 - 14/08/2009 } \\
\hline & $\lambda$ Trace & & $\lambda \operatorname{Max}$ & & $\lambda$ Trace & & $\lambda \operatorname{Max}$ & & $\lambda$ Trace & & $\lambda \operatorname{Max}$ & \\
\hline & critical valu & L & critical values & L & critical values & L & critical values & L & critical values & L & critical values & L \\
\hline$\lambda<1(5 \%),(1 \%)^{*}$ & - & 587,150 & - & 111,722 & - & 696,214 & - & 119,336 & - & 412,812 & - & 78,519 \\
\hline$\lambda<2(5$ & - & 475,428 & - & & - & 576,878 & - & & (95,99), (312,58) & 334,292 & $(71,68),(78,51)$ & 73,938 \\
\hline & - & 390,745 & - & & - & 4,722 & - & & 50,84), (2 & 260,354 & $(66,10),(7$ & 51,450 \\
\hline$<4(5$ & $(295,99),(312,58)$ & 322,846 & $(71,68),(78,5$ & 57,772 & $5,99),(312$ & 365,917 & $(71,68),(78$, & 80,914 & (208,97), (222,46) & 208,903 & $(60,29),(66,91)$ & 46,872 \\
\hline$\lambda<5(5$ & $(250,84),(263,94)$ & 265,073 & $(66,10),(72,96)$ & 50,043 & $(250,84),(263,94)$ & 285,002 & $(66,10),(72,96)$ & 63,230 & $(170,80),(182,51)$ & 162,031 & $(54,25),(60,81)$ & 37,778 \\
\hline$\lambda<6(5 \%),(1 \%)^{*}$ & $(208,97),(222,46)$ & 215,030 & $(60,29),(66,91)$ & 47,585 & $(208,97),(222,46)$ & 221,771 & $(60,29),(66,91)$ & 60,208 & $(136,61),(146,99)$ & 124,253 & $(48,45),(54,48)$ & 33,367 \\
\hline$\lambda<7(5$ & $(170,80),(182,51)$ & 167,445 & $(54,25),(60,81)$ & & $(170,80),(182$ & 161,563 & $(54,25),(60,81)$ & & $(104,94),(114,36)$ & 90,885 & $(42,48),(48,17)$ & 26,129 \\
\hline$\lambda<8(5 \%),(1 \%)^{*}$ & $(136,61),(146,99)$ & 129,451 & $(48,45),(54,48)$ & 30,949 & $(136,61),(146,99)$ & 119,705 & $(48,45),(54,48)$ & 37,851 & $(77,74),(85,78)$ & 64,755 & $(36,41),(41,58)$ & 24,568 \\
\hline
\end{tabular}


Table 6a. The A coefficient of the Flexible Multivariate GARCH model for the whole sample

\begin{tabular}{|c|c|c|c|c|c|c|c|c|c|c|c|c|c|c|}
\hline & & & & Flexib & Elagone & VECHM & der-me & overitier & (n) & & & & & \\
\hline & ATX & BEL & OMX & CAC & DAX & Athex & ISEQ & SPIMIB & LuxX & AEX & PSI & IBEX & FTSE100 & S\&P500 \\
\hline ATX & 0,111 & 0,109 & 0,059 & 0,076 & 0,083 & 0,090 & 0,086 & 0,097 & 0,095 & 0,088 & 0,099 & 0,091 & 0,098 & 0,044 \\
\hline BEL & & 0,134 & 0,067 & 0,076 & 0,096 & 0,099 & 0,099 & 0,114 & 0,109 & 0,104 & 0,107 & 0,108 & 0,116 & 0,075 \\
\hline OMX & & & 0,035 & 0,045 & 0,050 & 0,053 & 0,052 & 0,058 & 0,056 & 0,054 & 0,058 & 0,056 & 0,060 & 0,035 \\
\hline CAC & & & & 0,089 & 0,056 & 0,073 & 0,070 & 0,065 & 0,081 & 0,070 & 0,075 & 0,063 & 0,070 & 0,025 \\
\hline DAX & & & & & 0,094 & 0,071 & 0,073 & 0,085 & 0,074 & 0,054 & 0,080 & 0,079 & 0,085 & 0,057 \\
\hline Athex & & & & & & 0,100 & 0,076 & 0,085 & 0,080 & 0,081 & 0,083 & 0,080 & 0,087 & 0.041 \\
\hline ISEQ & & & & & & & 0,089 & 0,085 & 0,083 & 0,080 & 0,082 & 0,082 & 0,088 & 0.053 \\
\hline SP/MIB & & & & & & & & 0,100 & 0,089 & 0,089 & 0,097 & 0,096 & 0,102 & 0066 \\
\hline LuxX & & & & & & & & & 0,117 & 0,088 & 0,086 & 0,081 & 0,092 & 0,045 \\
\hline AEX & & & & & & & & & & 0,103 & 0,090 & 0,087 & 0,093 & 0,053 \\
\hline PSI & & & & & & & & & & & 0,110 & 0,095 & 0,097 & 0,055 \\
\hline IBEX & & & & & & & & & & & & 0,093 & 0,097 & 0,064 \\
\hline FTSE & & & & & & & & & & & & & 0,105 & 0,068 \\
\hline S\&P5C & & & & & & & & & & & & & & 0,068 \\
\hline
\end{tabular}

Table 6b. The A coefficient of the Flexible Multivariate GARCH model for the pre IAS period

\begin{tabular}{|c|c|c|c|c|c|c|c|c|c|c|c|c|c|c|}
\hline & & & & Flexibl & Diagonal & $\mathrm{VECH} \mathrm{mo}$ & el - the A & coefficient & pre IAS p & iod) & & & & \\
\hline & ATX & BEL & OMX & CAC & DAX & Athex & ISEQ & SPIMIB & LuxX & AEX & PSI & IBEX & FTSE100 & S\&P500 \\
\hline ATX & 0,083 & 0,078 & $-0,009$ & 0,064 & 0,052 & 0,065 & 0,069 & 0,059 & 0,074 & 0,067 & 0,059 & 0,061 & 0,036 & 0,020 \\
\hline BEL & & 0,161 & $-0,017$ & 0,078 & 0,113 & 0,114 & 0,095 & 0,114 & 0,066 & 0,126 & 0,090 & 0,107 & 0,065 & 0,076 \\
\hline OMX & & & 0,034 & $-0,002$ & $-0,016$ & $-0,007$ & $-0,013$ & $-0,028$ & 0,005 & $-0,014$ & $-0,007$ & $-0,011$ & $-0,057$ & $-0,007$ \\
\hline CAC & & & & 0,086 & 0,053 & 0,079 & 0,062 & 0,053 & 0,086 & 0,072 & 0,048 & 0,060 & 0,027 & 0,030 \\
\hline DAX & & & & & 0,089 & 0,072 & 0,065 & 0,085 & 0,026 & 0,090 & 0,06 & 0,079 & 0,051 & 0,066 \\
\hline hex & & & & & & 0,152 & 0,065 & & 0,065 & 0,095 & & 0,06 & & \\
\hline ISEQ & & & & & & 0,102 & 0,083 & 0,073 & 0,069 & 0,078 & 0,057 & 0,067 & 45 & 0,036 \\
\hline SP/MIB & & & & & & & & 0,094 & 0,043 & 0,090 & 0,070 & & & 0,061 \\
\hline & & & & & & & & & 0,141 & 0,060 & & & & 0,003 \\
\hline & & & & & & & & & & 0,102 & 0,074 & & 052 & 0,060 \\
\hline PSI & & & & & & & & & & & 0,081 & 0,070 & & 0,041 \\
\hline IBEX & & & & & & & & & & & & 0,078 & & 0,055 \\
\hline FTSE100 & & & & & & & & & & & & & 0,104 & 0,028 \\
\hline S\&P500 & & & & & & & & & & & & & & 0,066 \\
\hline
\end{tabular}


Table 6c. The A coefficient of the Flexible Multivariate GARCH model for the post IAS period

\begin{tabular}{|c|c|c|c|c|c|c|c|c|c|c|c|c|c|c|}
\hline & ATX & BEL & OMX & $\begin{array}{l}\text { Flexib } \\
\text { CAC }\end{array}$ & $\frac{\text { Diagonal }}{\mathrm{DAX}}$ & $\frac{V E C H ~ m c}{\text { Vthex }}$ & $\begin{array}{l}\text { lel - the A } \\
\text { ISEO }\end{array}$ & $\frac{\text { coeffIIIent }}{\text { SPIMIB }}$ & post IAS & 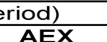 & & & & \\
\hline ATX & 0,143 & $\begin{array}{l}\text { BEL } \\
0,111\end{array}$ & $\frac{0 M x}{0,108}$ & $\frac{C A C}{0,102}$ & DAX & $\begin{array}{c}\text { Athex } \\
0,113\end{array}$ & $\frac{\text { ISEQ }}{0.087}$ & $\frac{\text { SP/MIB }}{0.055}$ & $\frac{\text { LuxX }}{0.117}$ & AEX & $\frac{\text { PSI }}{0.140}$ & $\begin{array}{l}\text { IBEX } \\
0.119\end{array}$ & $\begin{array}{r}\text { FTSE100 } \\
0.054\end{array}$ & $\begin{array}{r}\text { S\&P500 } \\
0,067\end{array}$ \\
\hline BEL & & 0,119 & 0,090 & 0,079 & 0,102 & 0,091 & 0,053 & $-0,002$ & 0,100 & 0,105 & 0,114 & 0,118 & 0,092 & 0,064 \\
\hline OMX & & & 0,089 & 0,074 & 0,097 & 0,089 & 0,068 & 0,040 & 0,092 & 0,100 & 0,111 & 0,097 & 0,047 & 0,060 \\
\hline CAC & & & & 0,117 & 0,083 & 0,089 & 0,064 & 0,041 & 0,095 & 0,085 & 0,110 & 0,080 & 0,039 & 0,013 \\
\hline DAX & & & & & 0,111 & 0,101 & 0,078 & 0,047 & 0,107 & 0,115 & 0,126 & 0,110 & 0,051 & 0,073 \\
\hline Athex & & & & & & 0,107 & 0,076 & 0,047 & 0,097 & 0,104 & 0,116 & 0,100 & 0,044 & 0,055 \\
\hline ISEQ & & & & & & & 0,069 & 0,066 & 0,075 & 0,080 & 0,091 & 0,065 & 0,004 & 0,047 \\
\hline SP/MIB & & & & & & & & 0,103 & 0,047 & 0,048 & 0,057 & 0,014 & $-0,060$ & 0,027 \\
\hline LuxX & & & & & & & & & 0,117 & 0,110 & 0,121 & 0,103 & 0,049 & 0,059 \\
\hline $\begin{array}{l}\text { AEX } \\
\text { PSI }\end{array}$ & & & & & & & & & & 0,118 & 0,129 & 0,114 & 0,053 & O,075 \\
\hline IBEX & & & & & & & & & & & 0,150 & 0,124 & 0,056 & $\begin{array}{l}0,070 \\
0,073\end{array}$ \\
\hline FTSE100 & & & & & & & & & & & & & 0,103 & 0,032 \\
\hline S\&P500 & & & & & & & & & & & & & & 0,080 \\
\hline
\end{tabular}

Table 7a. The B coefficient of the Flexible Multivariate GARCH model for the whole sample

\begin{tabular}{|c|c|c|c|c|c|c|c|c|c|c|c|c|c|c|}
\hline & & & & Flexib & Diagon & IVECH m & del-the & 3 coefficier & (whole $\mathrm{p}$ & lod) & & & & \\
\hline & ATX & BEL & OMX & CAC & DAX & Athex & ISEQ & SP/MIB & LuxX & AEX & PSI & IBEX & FTSE100 & S\&P500 \\
\hline ATX & 0,873 & 0,861 & 0,913 & 0,886 & 0,880 & 0,877 & 0,885 & 0,830 & 0,869 & 0,763 & 0,874 & 0,792 & 0,875 & 0,897 \\
\hline BEL & & 0,855 & 0,904 & 0,877 & 0,871 & 0,869 & 0,876 & 0,822 & 0,861 & 0,755 & 0,865 & 0,784 & 0,866 & 0,888 \\
\hline OMX & & & 0,964 & 0,930 & 0,928 & 0,920 & 0,928 & 0,890 & 0,912 & 0,771 & 0,916 & 0,857 & 0,924 & 0,941 \\
\hline CAC & & & & 0,905 & 0,896 & 0,894 & 0,901 & 0,845 & 0,885 & 0,777 & 0,890 & 0,807 & 0,891 & 0,914 \\
\hline DAX & & & & & 0,900 & 0,887 & 0,894 & 0,867 & 0,879 & 0,729 & 0,883 & 0,838 & 0,893 & 0,907 \\
\hline Athex & & & & & & 0,887 & 0,892 & 0,837 & 0,877 & 0,769 & 0,881 & 0,798 & 0,882 & 0,904 \\
\hline ISEQ & & & & & & & 0,902 & 0,844 & 0,884 & 0,776 & 0,888 & 0,805 & 0,890 & 0,912 \\
\hline SP/MIB & & & & & & & & 0,893 & 0,829 & 0,577 & 0,833 & 0,889 & 0,865 & 0,855 \\
\hline LuxX & & & & & & & & & 0,871 & 0,762 & 0,873 & 0,791 & 0,874 & 0,896 \\
\hline AEX & & & & & & & & & & 0,897 & 0,766 & 0,492 & 0,722 & 0,787 \\
\hline PSI & & & & & & & & & & & 0,879 & 0,795 & 0,879 & 0,901 \\
\hline IBEX & & & & & & & & & & & & 0,900 & 0,836 & 0,816 \\
\hline FTSE100 & & & & & & & & & & & & & 0,891 & 0,902 \\
\hline S\&P500 & & & & & & & & & & & & & & 0,926 \\
\hline
\end{tabular}


Table 7b. The B coefficient of the Flexible Multivariate GARCH model for the pre IAS period

\begin{tabular}{|c|c|c|c|c|c|c|c|c|c|c|c|c|c|c|}
\hline & & & & Flexib| & Diagona & VECH mc & el - the B & coefficien & (pre IAS F & iiod) & & & & \\
\hline & ATX & BEL & OMX & CAC & DAX & Athex & ISEQ & SP/MIB & LuxX & AEX & PSI & IBEX & FTSE100 & S\&P500 \\
\hline ATX & 0,859 & 0,835 & 0,830 & 0,872 & 0,873 & 0,789 & 0,859 & 0,857 & 0,816 & 0,820 & 0,871 & 0,846 & 0,864 & 0,879 \\
\hline BEL & & 0,831 & 0,809 & 0,864 & 0,865 & 0,782 & 0,859 & 0,855 & 0,818 & 0,824 & 0,864 & 0,847 & 0,856 & 0,876 \\
\hline OMX & & & 0,966 & 0,859 & 0,852 & 0,779 & 0,856 & 0,786 & 0,815 & 0,693 & 0,855 & 0,734 & 0,853 & 0,845 \\
\hline CAC & & & & 0,904 & 0,903 & 0,817 & 0,897 & 0,887 & 0,854 & 0,849 & 0,902 & 0,876 & 0,894 & 0,913 \\
\hline DAX & & & & & 0,906 & 0,817 & 0,897 & 0,890 & 0,855 & 0,856 & 0,903 & 0,881 & 0,894 & 0,914 \\
\hline Athex & & & & & & 0,741 & 0,811 & 0,802 & 0,773 & 0,767 & 0,816 & 0,791 & 0,809 & 0,825 \\
\hline ISEQ & & & & & & & 0,896 & & 0,854 & 0,843 & 0,897 & 0,869 & 0,888 & 0,908 \\
\hline SPIMIB & & & & & & & & 0,897 & 0,839 & & 0,888 & 0,900 & 0,878 & 0,906 \\
\hline LuxX & & & & & & & & & 0,816 & 0,8 & 0,85 & 0,828 & 0,8 & 0,865 \\
\hline & & & & & & & & & & 0,890 & 0,85 & 0,901 & 0,8 & 0,877 \\
\hline PS & & & & & & & & & & & 0,904 & 0,878 & 0,893 & 0,913 \\
\hline IBE & & & & & & & & & & & & 0,917 & & 0,901 \\
\hline FTSE100 & & & & & & & & & & & & & 0,886 & 0,903 \\
\hline S\&P500 & & & & & & & & & & & & & & 0,929 \\
\hline
\end{tabular}

Table 7c. The B coefficient of the Flexible Multivariate GARCH model for the post IAS period

\begin{tabular}{|c|c|c|c|c|c|c|c|c|c|c|c|c|c|c|}
\hline \multirow[b]{2}{*}{ 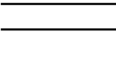 } & \multicolumn{14}{|c|}{ Flexible Diagonal VECH model - the B coefficient } \\
\hline & ATX & BEL & OMX & CAC & DAX & Athex & ISEQ & SP/MIB & LuxX & AEX & PSI & IBEX & FTSE100 & S\&P500 \\
\hline ATX & 0,850 & 0,772 & 0,812 & 0,860 & 0,862 & 0,867 & 0,716 & 0,759 & 0,863 & 0,726 & 0,847 & 0,843 & 0,631 & 0,880 \\
\hline BEL & & 0,871 & 0,714 & 0,782 & 0,785 & 0,795 & 0,424 & 0,618 & 0,785 & 0,775 & 0,772 & 0,804 & 0,650 & 0,800 \\
\hline OMX & & & 0,904 & 0,823 & 0,824 & 0,828 & 0,770 & 0,886 & 0,827 & 0,825 & 0,810 & 0,760 & 0,374 & 0,842 \\
\hline CAC & & & & 0,873 & 0,874 & 0,879 & 0,725 & 0,769 & 0,875 & 0,736 & 0,858 & 0,855 & 0,640 & 0,892 \\
\hline DAX & & & & & 0,878 & 0,881 & 0,726 & 0,769 & 0,877 & 0,737 & 0,861 & 0,858 & 0,644 & 0,894 \\
\hline Athex & & & & & & 0,888 & 0,722 & 0,772 & 0,882 & 0,746 & 0,865 & 0,863 & 0,649 & 0,899 \\
\hline ISEQ & & & & & & & 0,931 & 0,799 & 0,728 & 0,519 & 0,711 & 0,645 & 0,340 & 0,742 \\
\hline SP/MIB & & & & & & & & 0,897 & 0,772 & 0,780 & 0,756 & 0,683 & 0,26 & 0,787 \\
\hline LuxX & & & & & & & & & 0,880 & 0,739 & 0,862 & 0,858 & 0,642 & 0,895 \\
\hline AEX & & & & & & & & & & 0,876 & 0,726 & 0,695 & 0,328 & 0,753 \\
\hline PSI & & & & & & & & & & & 0,846 & 0,842 & 0,631 & 0,878 \\
\hline IBEX & & & & & & & & & & & & 0,865 & 0,721 & 0,874 \\
\hline FTSE1 & & & & & & & & & & & & & 0,897 & 0,654 \\
\hline S\&P500 & & & & & & & & & & & & & & 0,913 \\
\hline
\end{tabular}


covariance matrix, and the $H_{(.)}$one represents the conditional covariance matrix.

Based on the moving average representation of the estimated VAR models, the impulse response analysis, tests the dynamics of the interrelationships of the EMU capital markets. In this direction, possible shocks in current innovations of the aforementioned models, would cause asymmetric effects on the relationships of the time series, and thus, impulse response analysis investigates the dynamics of the short run interactions of the financial indices examined.

\section{Empirical Results}

Figures 1, 2 of the appendix, represent the spot prices and the returns of the major financial indices of the EU-12, the UK and the US. As is obvious, with an exception of the ATX index, there are two peak periods, in 2001 and in 2008 which are characterized by high volatility regimes. In Tables $2 a, b$ and $c$ are the descriptive statistics for the whole, the pre and post IAS period. According to these statistics, the OMXH financial index is the most volatile time series, the financial indices are negatively skewed, evidence of risk averted investing profile, and their distribution is much more leptokurtic than the normal one. Tables $3 \mathrm{a}, \mathrm{b}$ and $\mathrm{c}$ contain the pairwise correlations between the returns of the financial indices for the whole, and the pre and post IAS periods. As is shown, the post IAS period is characterized by high correlations, indicating tighter relationships in the second sub period. More specifically, only $9 \%$ of the pairwise correlations exceeds the threshold value of the correlation coefficient 0,8 , in the pre IAS period and more than $47 \%$ for the post IAS period. According to the unit root and stationarity tests

Figure 3. Smoothed Regime probabilities of the MS-VECM model

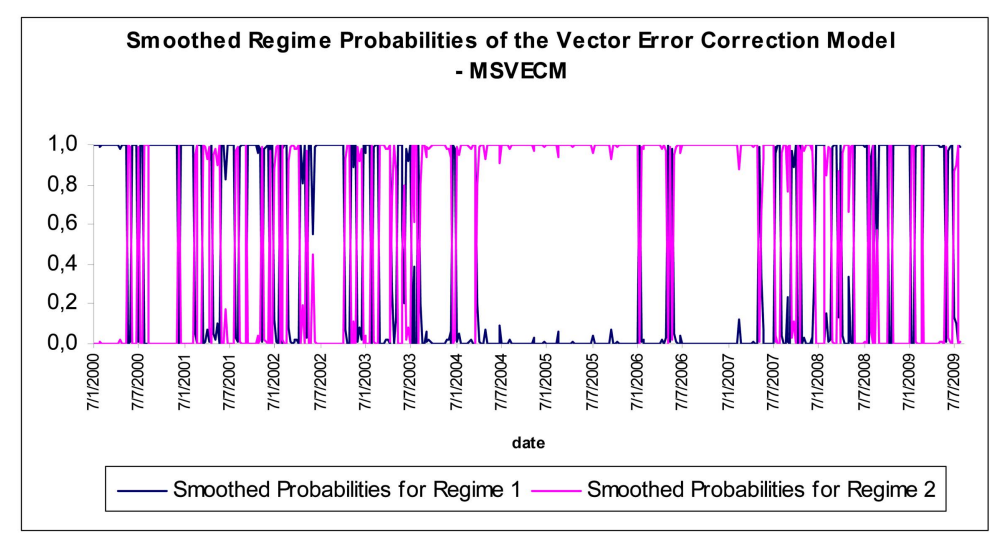


Figure 4. Regime Shift probabilities of the volatility process of $A T X$

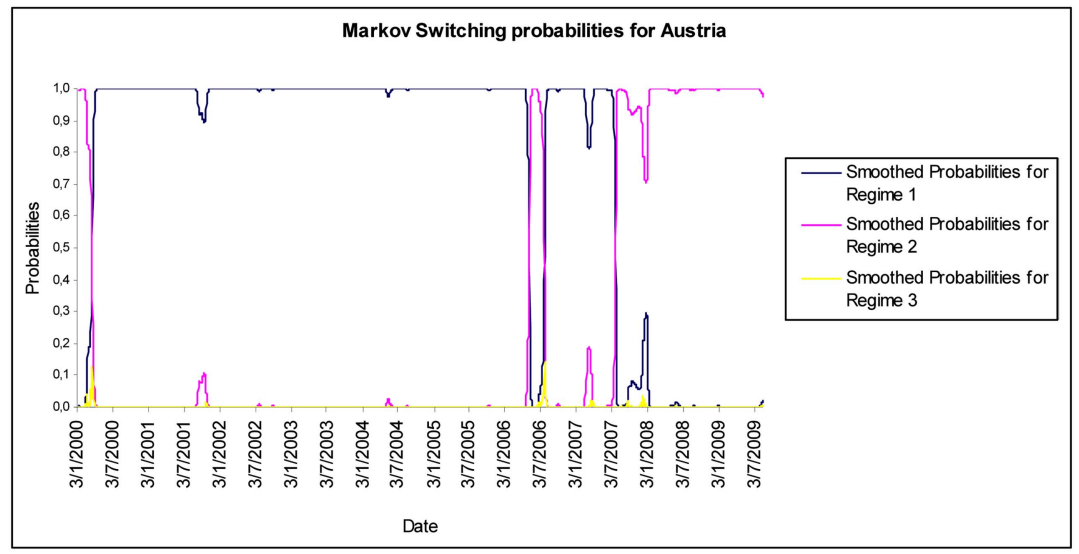

Figure 5. Regime Shift probabilities of the volatility process of Bel20

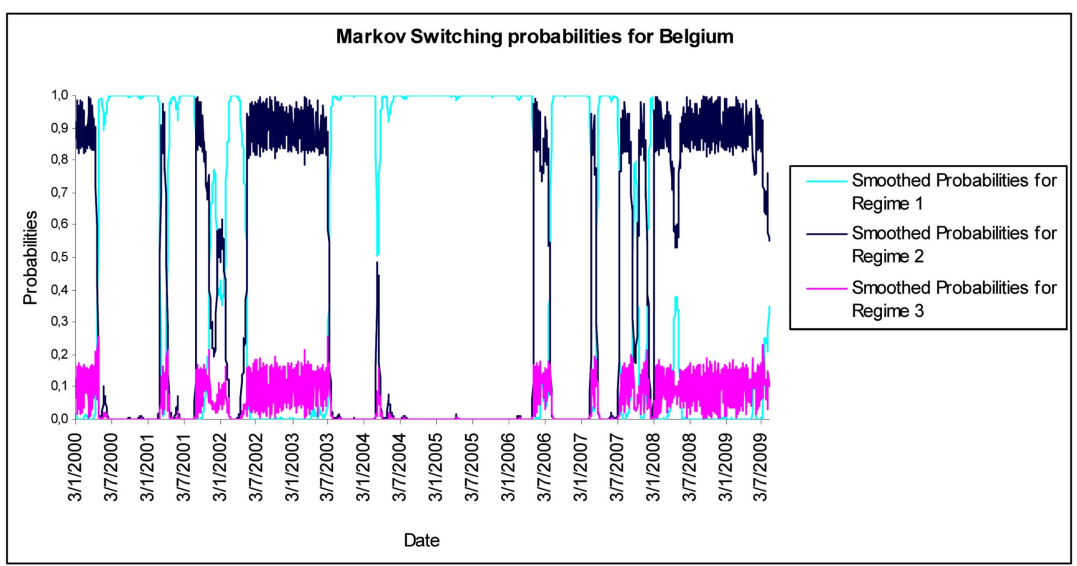

Figure 6. Regime Shift probabilities of the volatility process of OMX Helsinki 25

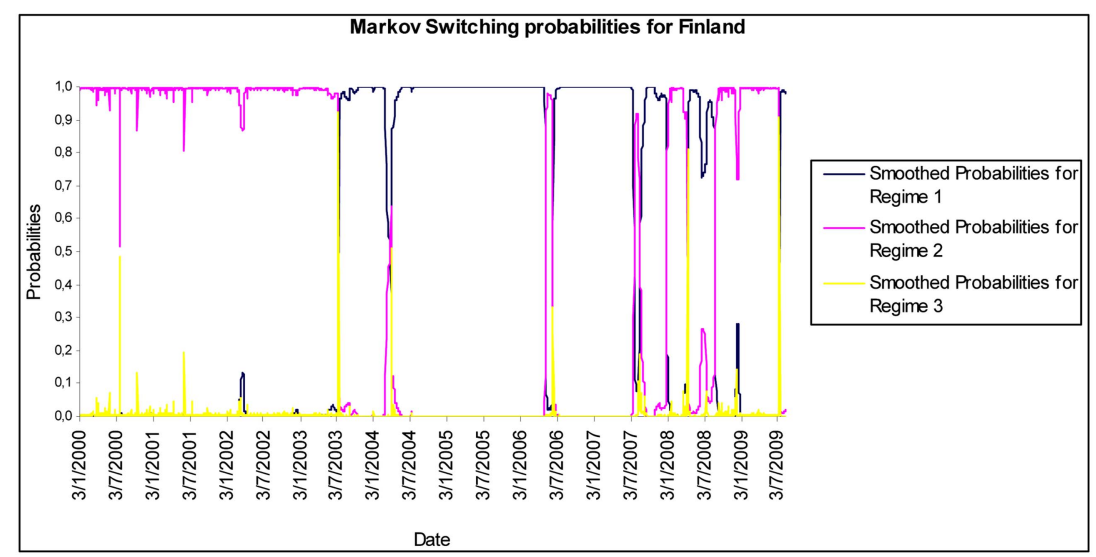


Figure 7. Regime Shift probabilities of the volatility process of $C A C 40$

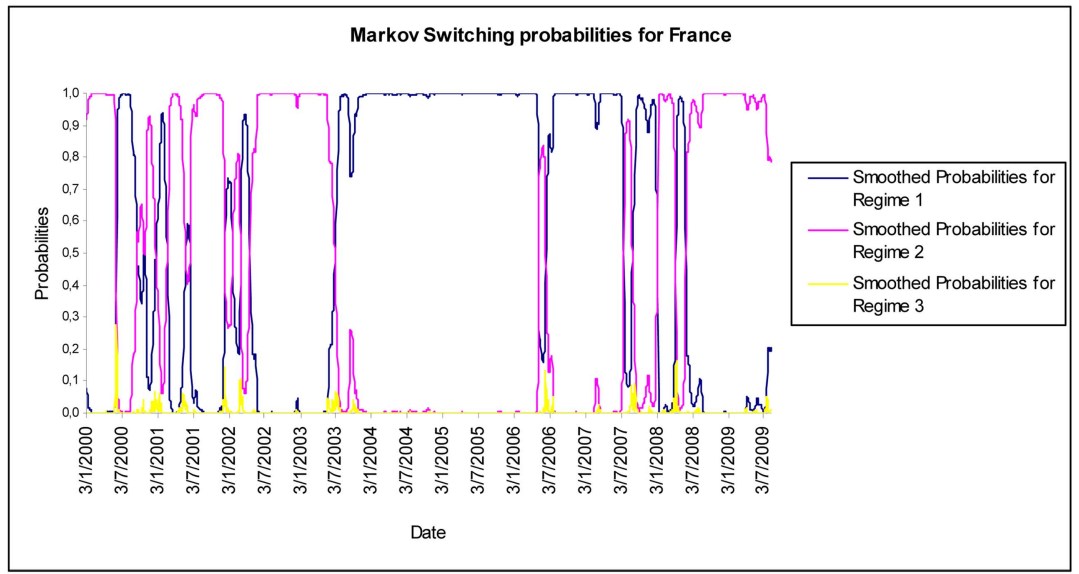

Figure 8. Regime Shift probabilities of the volatility process of $D A X$

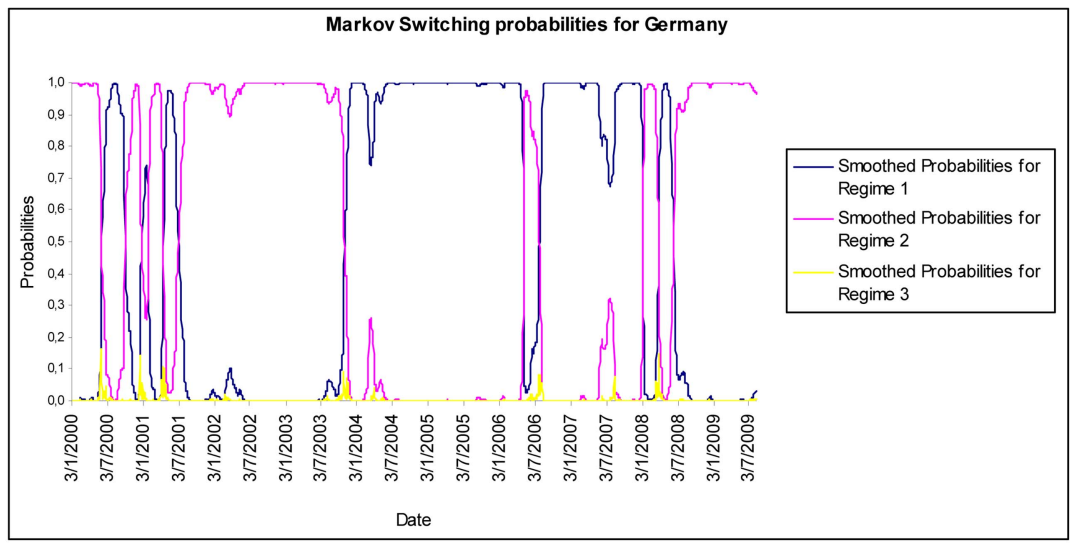

Figure 9. Regime Shift probabilities of the volatility process of Athex 20

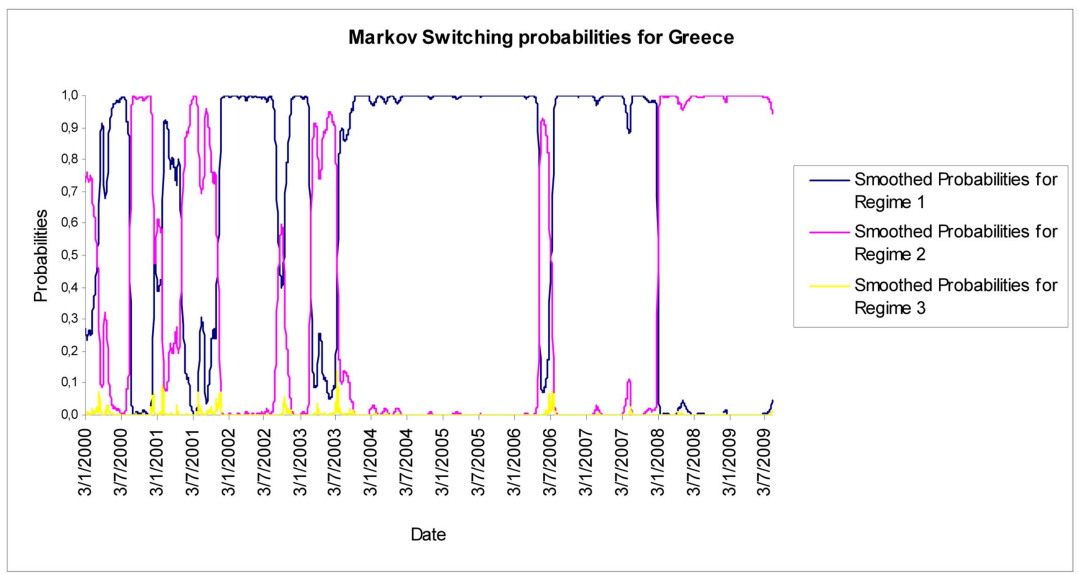


Figure 10. Regime Shift probabilities of the volatility process of ISEQ 20

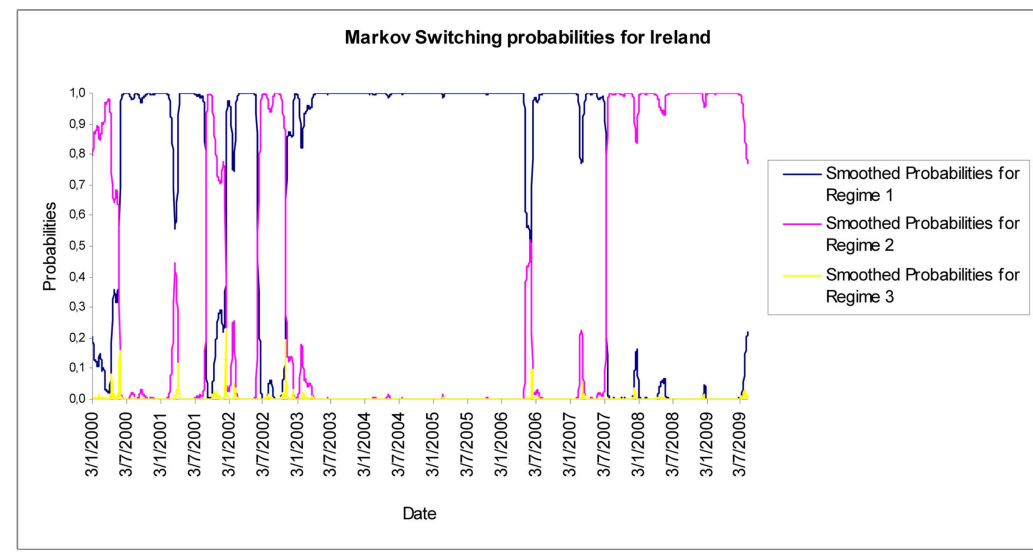

Figure 11. Regime Shift probabilities of the volatility process of $S \& P / M I B$

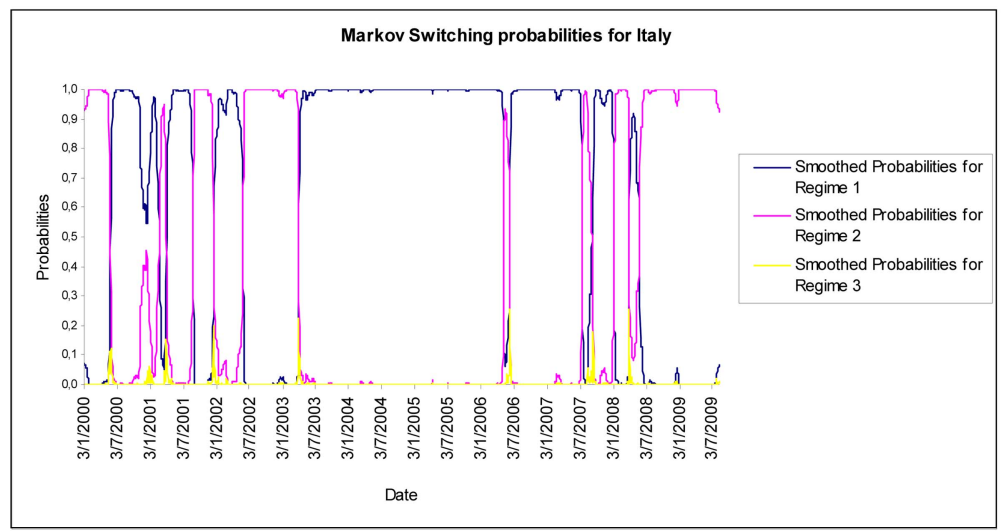

Figure 12. Regime Shift probabilities of the volatility process of LuxX Index

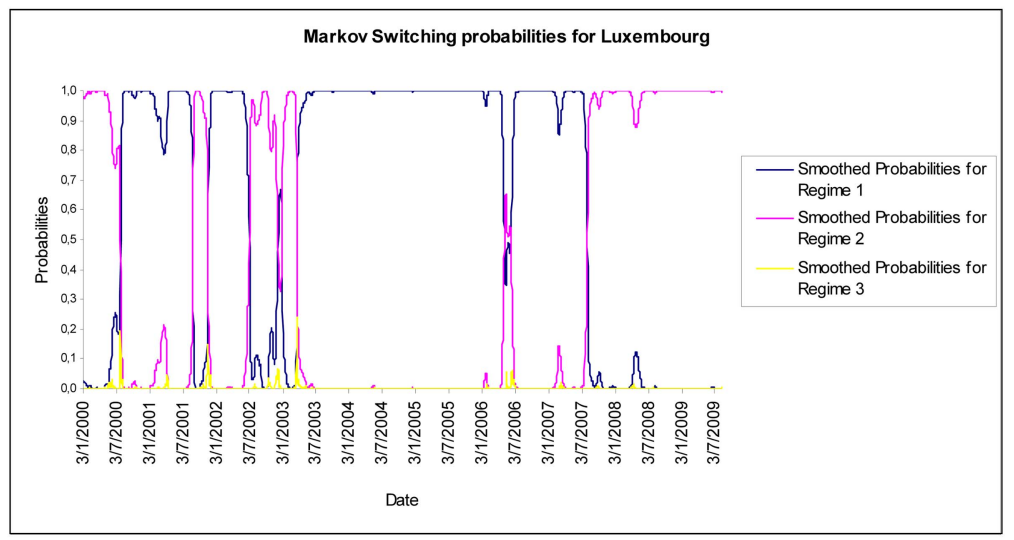


Figure 13. Regime Shift probabilities of the volatility process of $A E X$ index

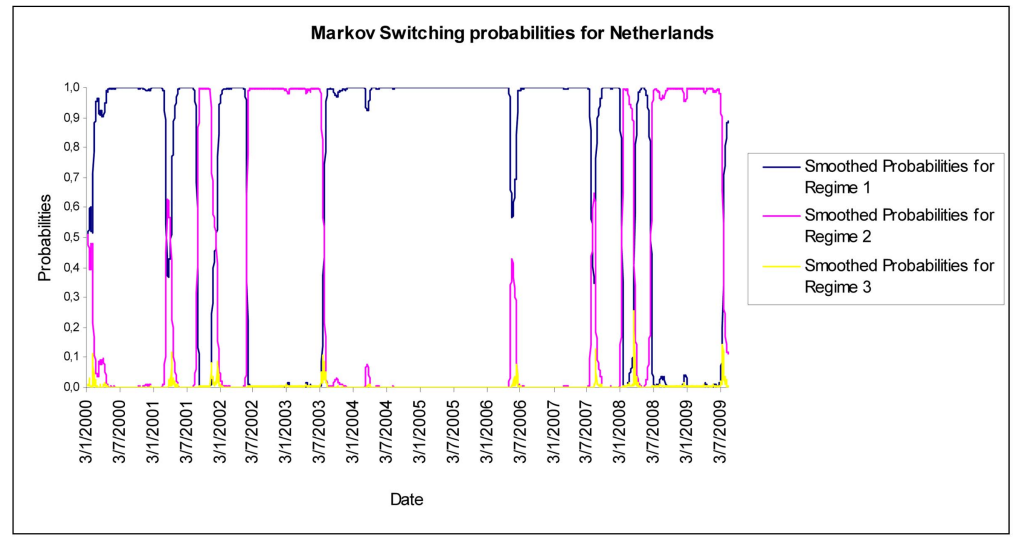

Figure 14. Regime Shift probabilities of the volatility process of PSI-20

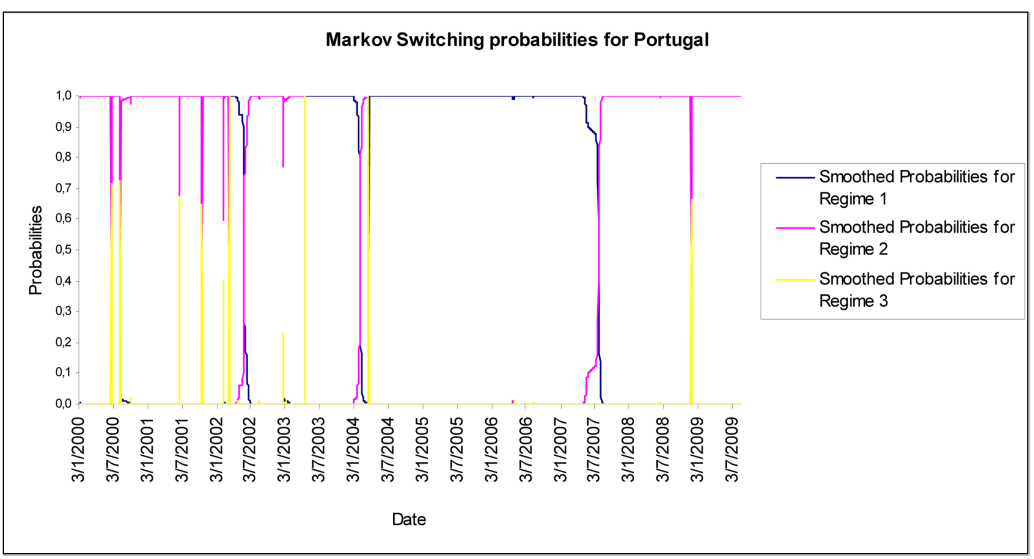

Figure 15. Regime Shift probabilities of the volatility process of IBEX 35

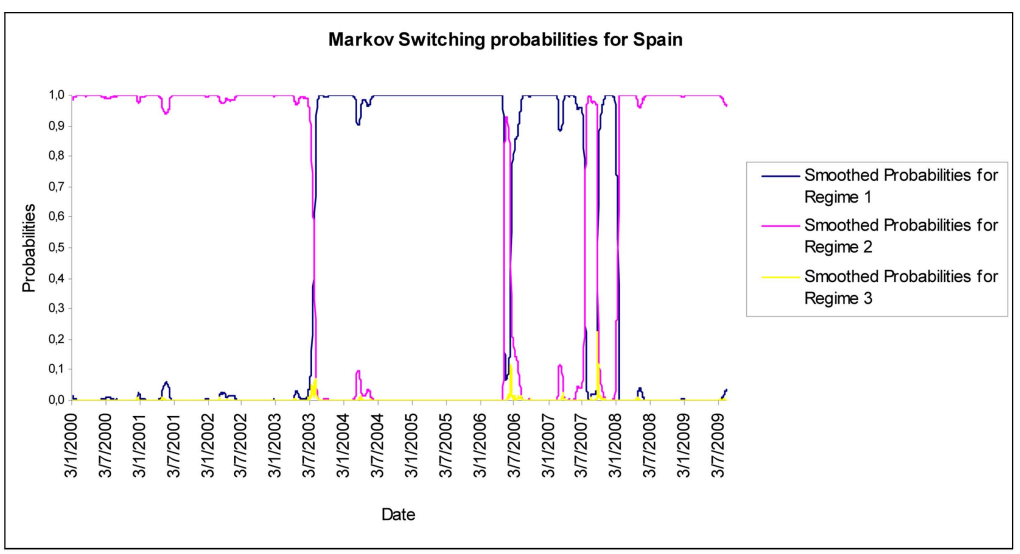


Figure 16. Impulse Response analysis for the ATX financial index (all, pre \& post)

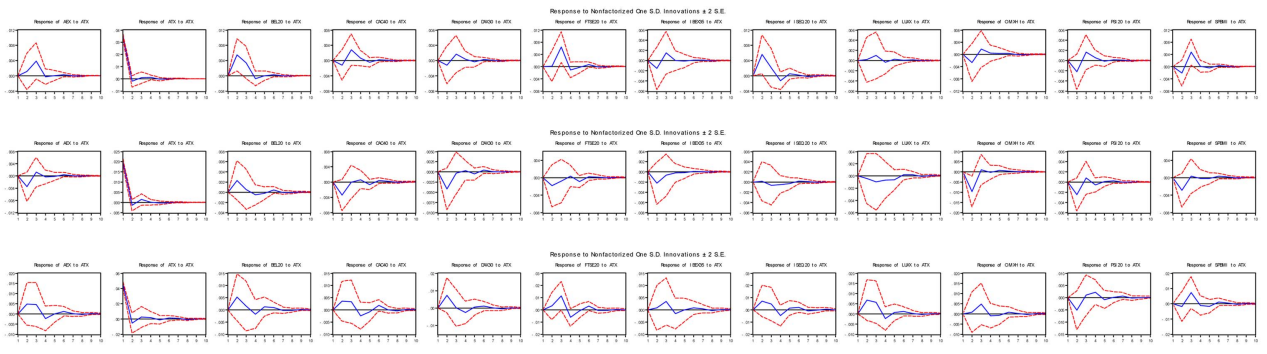

Figure 17. Impulse Response analysis for the BEL 20 financial index (all, pre \& post)

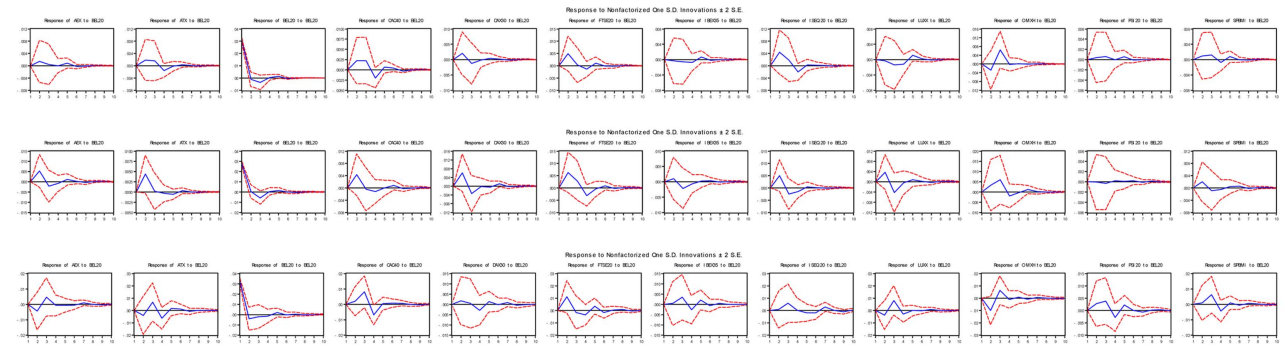

Figure 18. Impulse Response analysis for the OMX financial index (all, pre \& post)

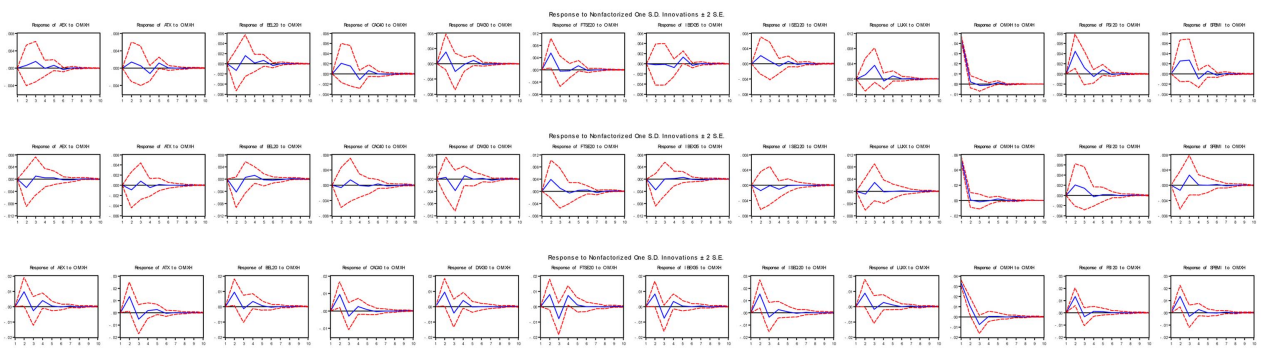

Figure 19. Impulse Response analysis for the CAC40 financial index (all, pre \& post)

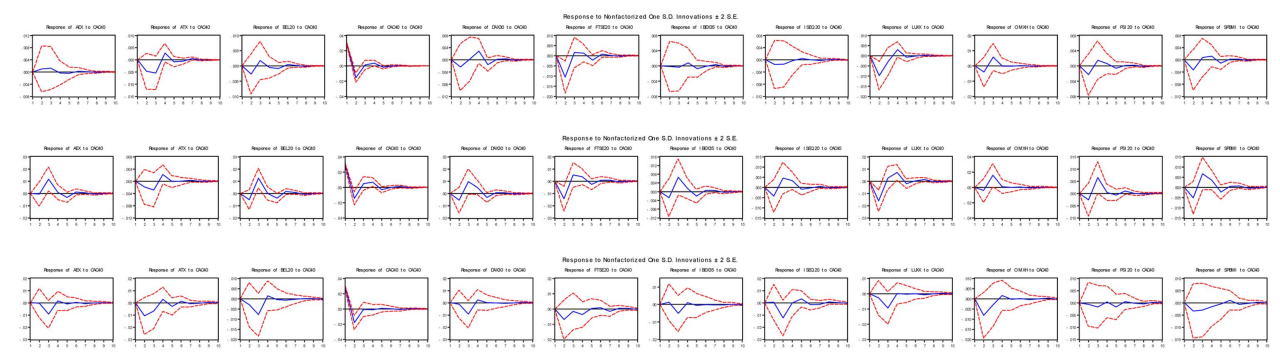


Figure 20. Impulse Response analysis for the DAX financial index (all, pre \& post)

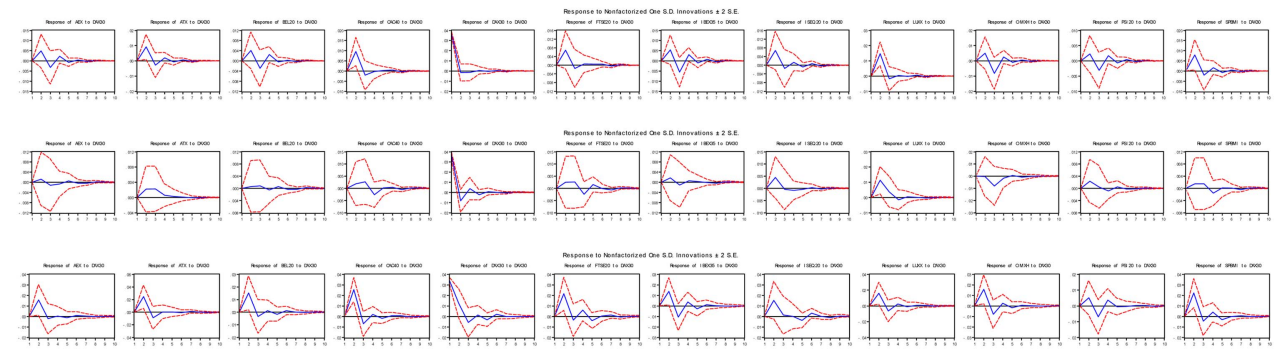

Figure 21. Impulse Response analysis for the FTSE20 financial index (all, pre, post)

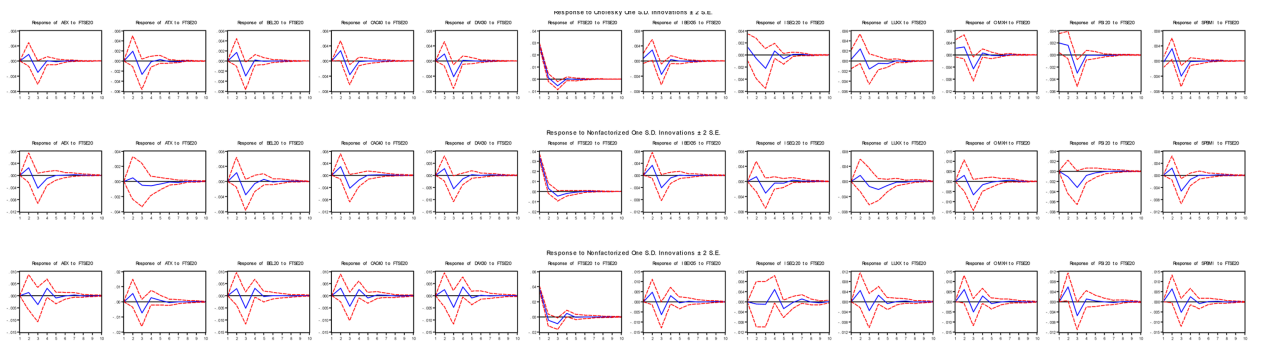

Figure 22. Impulse Response analysis for the ISEQ20 financial index (all, pre, post)

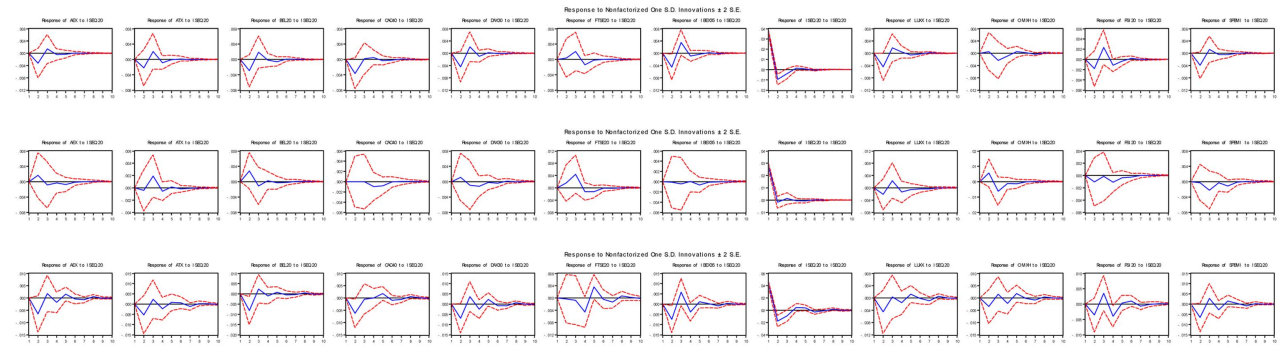

Figure 23. Impulse Response analysis for the SP MIB financial index (all, pre, post)

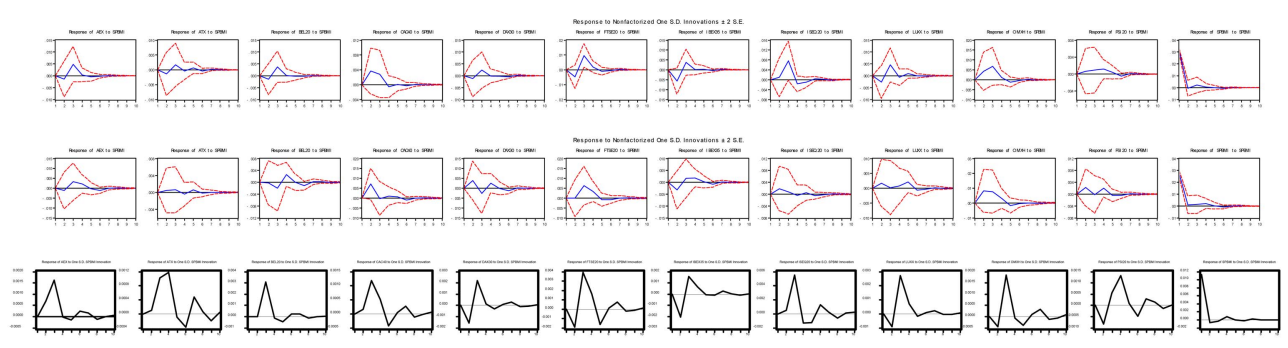


Figure 24. Impulse Response analysis for the LuxX financial index (all, pre \& post)

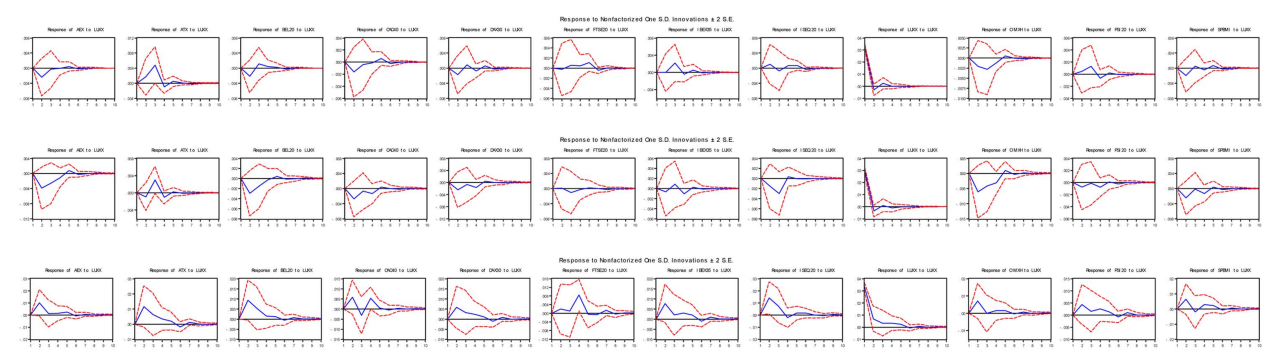

Figure 25. Impulse Response analysis for the AEX financial index (all, pre \& post)

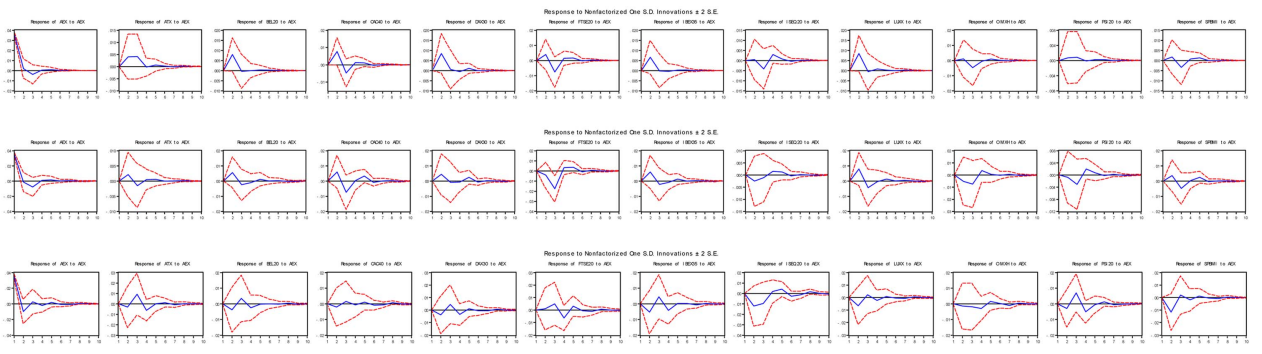

Figure 26. Impulse Response analysis for the PSI 20 financial index (all, pre \& post)

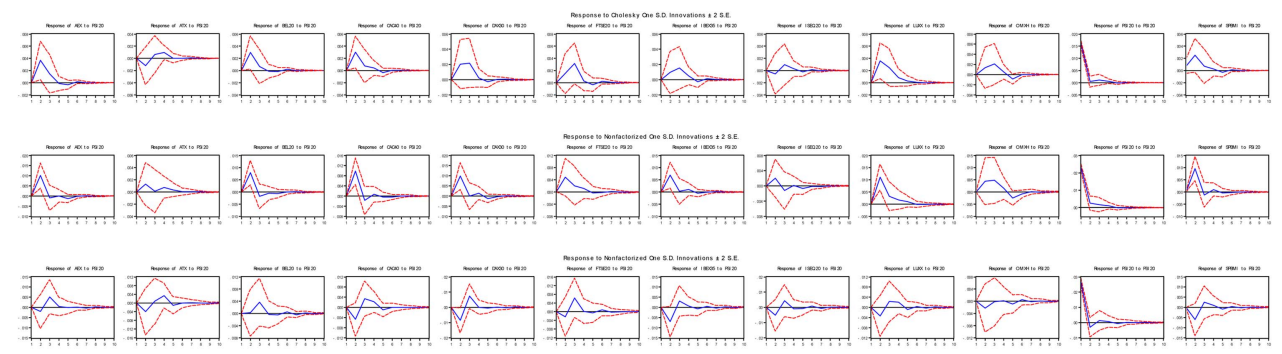

of Table 4, the time series in levels are not stationary, in contrast to their returns which do not have unit roots. In Table 5 are the results of the Johansen cointegration analysis for the whole and the pre and post time periods. According to the maximum likelihood statistic ( $\lambda$ Max) there exist three common stochastic trends for the whole time period, a result which seems to be inflated for the pre IAS period, reaching the value five, while for the post IAS period there are only two cointegration equations. This is very interesting, since it represents strong evidence of tighter cointegration structures in the post IAS time period, indicating that the 
Figure 27. Impulse Response analysis for the Ibex 35 financial index (all, pre \& post)

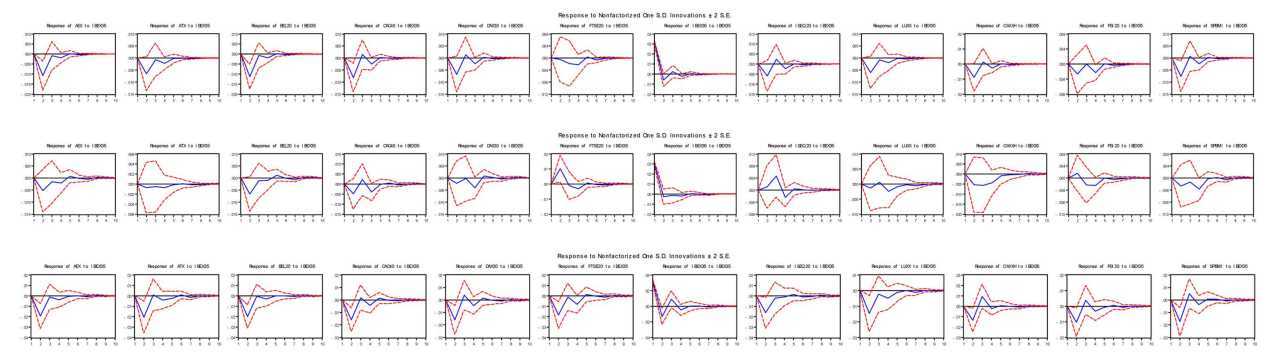

informational efficiency and the direct transparency of new information due to the IAS system has improved. Figure 3, illustrates the smoothed probabilities of the regime shifts of the MS-VECM model, according to which the short run readjustments around the common stochastic trends are governed by a nonobservable variable of the structural changes. According to this figure, in the period around the obligatory adoption of the IAS (2004-2006), the second regime of the VECM model, the low variance regime, governs the system, indicating an intenseness of the short run readjustments around the equilibrium state of the financial markets, which are in line with the informational efficiency of the financial system. Tables 6 and 7 present the coefficients ' $A$ ' and ' $B$ ' of the multivariate GARCH models (14 dimensions). According to a comparative analysis between the pre and post IAS period the rate of the accumulated new information has increased due to the adoption of the IAS structure, in contrast to the volatility persistence which is reduced. According to Figures 4 to 15, where the SWARCH smoothed regime probabilities are shown, there is an decrease in volatility in all financial indices around the date of the IAS obligatory adoption (1/ $1 / 05$ ) in a range of one to two years, excepting the ATX index. Finally according to the impulse response analysis, Figures 16 to 27 of the appendix, the adoption of IAS strengthens the magnitude and the persistence of the dependencies of the EMU financial markets, with an exception to the CAC 40, S\&P/MIB and PSI 20 financial indices.

\section{Conclusion}

The objective of our paper was the investigation of the implications of the IAS harmonization on the interdependences of the EU financial markets, the informational efficiency and the spillover effects. To this end, we applied regime 
shift econometric methods and found evidence that the common accepted accounting platform, which was adopted obligatory in 2005 , has affected the way EU financial markets inter-react with each other. More specifically, the long run equilibrium structure is better determined, due to the IAS adoption, since the cointegration vectors are reduced from five to two in the post IAS period. This is very important with many implications for international finance, because the arbitrage opportunities due to diversification benefits are eliminated. Moreover, the spillover effect dynamics show a higher rate of anticipated information, with lower persistence of volatility.

Received 1 May 2011, Revised 30 May 2011, Accepted 7 June 2011

\section{References}

Armstrong, C.S, Barth, M.E., Jagolinzer, A.D. \& Riedl, E.J. Market Reaction to the Adoption of IFRS in Europe, (forthcoming), The Accounting Review.

Al-Shiab, M.S. (2008), "The Effectiveness of International Financial Reporting Standards Adoption on Cost of Equity Capital: A Vector Error Correction Model", The International Journal of Business, 13, 271-298.

Brealey R.A. (1999), "Roundtable: The future of exchanges in an integrated Europe", European Financial Management, 5(2), pp. 281-303.

Davidson, J. E. H., Hendry, D. F., Srba, F. \& Yeo, S. (1978), "Econometric modeling of the aggregate time series relationship between consumers' expenditure and income in the United Kingdom", Economic Journal, 88, 661-692.

Dewing, I.P. \& Russell, P.O. (2008), "Financial Integration in the EU: The First Phase of EU Endorsement of International Accounting Standards", Journal of Common Market Studies, 46, 243-264.

Dickey, D. A. \& Fuller, W. A. (1979), "Distribution of the Estimates for Autoregressive Time Series with a Unit Root", Journal of American Statistical Association, 74, pp. 427-431.

Gray, S.J. (1980), "The Impact of International Accounting Differences from a SecurityAnalysis Perspective: Some European Evidence", Journal of Accounting Research, 18(1), 64-76.

Gonzalo, J. \& Granger C. (1995), "Estimation of Common Long-Memory Components in Cointegrated Systems", Journal of Business \& Economic Statistics, 13, pp. 27-35.

Hamilton, J. D. \& Susmel, R. (1994), "Autoregressive Conditional Heteroskedasticity and Changes in Regime", Journal of Econometrics, 64, pp. 307-333.

Hardouvelis, G.A., Malliaropulos, D. \& Priestley, R. (2006), "EMU and European Stock Market Integration", Journal of Business, 79.

Haug, A.A., MacKinnon, J.G. \& Michelis, L. (2000), "European Monetary Union: a 
cointegration analysis", Journal of International Money and Finance, 19, pp. 419432.

Hopwood, A.G. (1994), "Some reflections on The harmonization of accounting within the EU", International Journal of Business, 13, 3 .

Johansen, S. (1988), "Statistical Analysis of Cointegrating Vectors", Journal of Economic Dynamics and Control, 12, pp. 231-254.

Johansen, S. \& Juselius, K. (1990), "Maximum Likelihood Estimation and Inference on Cointegration with Applications to the Demand for Money", Oxford Bulletin of Economics and Statistics UK, 52, pp. 169-210.

Johansen, S. (1991), "Estimation and Hypothesis testing of Cointegration Vectors in Gaussian Vector Autoregressive Models", Econometrica, 59, pp. 1551-1580.

Johansen, S. \& Juselius, K. (1992), "Testing Structural Hypothesis in a Multivariate Cointegration Analysis of the PPP and UIP for UK", Journal of Econometrics, 53, pp. 211-244.

Johansen, S. \& Juselius, K. (1994), "Identification of the Long-Run and the Short-Run Structure", An Application to the ISLM model. Journal of Econometrics, 63, pp. 7 36.

Krolzig, H.M. (1996), "Statistical Analysis of Cointegrated VAR Process with Markovian Regime Shifts", SFB 373 Discussion Paper 25/1996.

Krolzig, H.M. (1997), "Markov Switching Vector Autoregressions", Modelling Statistical Inference and Application to Business Cycle Analysis, Springer Verlag 1997.

Kwiatkowski, D., Phillips, P.C.B., Schmidt, P. and Shin, Y. (1992), "Testing the null of stationarity against the alternative of a unit root: How sure are we that economic time series have a unit root?", Journal of Econometrics, 54, pp. 159-178.

Ledoit, O., Pedro, S.A. \& Wolf, M. (2002), "Flexible Multivariate GARCH Modeling with an Application to International Stock Markets", The Review of Economic and Statistics, 85, pp. 735-747.

Meulen, S., Gaeremynck, A. \& Willekens, M. (2007), "Attribute differences between U.S. GAAP and IFRS earnings: An exploratory study", The International Journal of Accounting, 42, pp. 143-147.

Schipper, K. (2005), "The introduction of International Accounting Standards in Europe: Implications for international convergence", European Accounting Review, 14, pp. 101-126.

Siriopoulos C. (2000), "EDITORIAL, The Integration of European Financial Markets And Its Importance For Economic Growth And Financial Stability: Where We Are Now And What We Expect", European Research Studies Journal, vol. 0(1-2), pp. 3-10.

Sunder, S. (2002), "Regulatory competition among accounting standards within and across international boundaries", Journal of Accounting and Public Policy 21, pp. 219-234.

Whittington, G. (2005), "The adoption of International Accounting Standards in the European Union”, European Accounting Review, 14, pp. 127-153. 